\title{
SPECIAL ISSUE
}

Policy Implementation as an Instrument to Achieve Educational

Equity in the Community College Context

\section{education policy analysis archives}

A peer-reviewed, independent, open access, multilingual journal

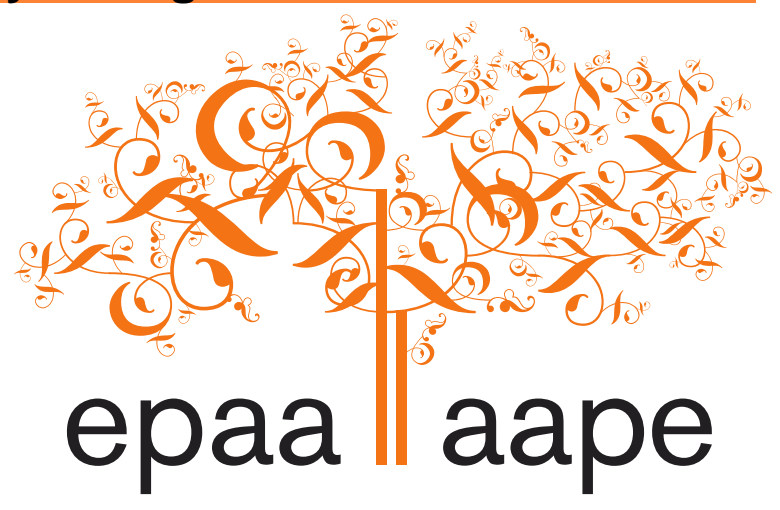

Arizona State University

\section{Opportunity for All? \\ The Differential Impacts of North Carolina's Revised Comprehensive Articulation Agreement by Race/Ethnicity}

\author{
Rachel E. Worsham \\ Melissa Whatley \\ North Carolina State University \\ \& \\ Jonathan E. Loss \\ Catawba Valley Community College \\ United States
}

Citation: Worsham, R. E., Whatley, M., \& Loss, J. E. (2021). Opportunity for all? The differential impacts of North Carolina's revised comprehensive articulation agreement by race/ethnicity. Education Policy Analysis Archives, 29(28). https://doi.org/10.14507/epaa.29.5385 This article is part of the special issue, Policy Implementation as an Instrument to Achieve Educational Equity in the Community College Context, guest edited by Eric R. Felix, H. Kenny Nienhusser, Ángel Gonzalez, Luz Burgos-López.

Abstract: Transfer articulation agreements are employed by institutions of higher education and
state legislatures alike to improve transfer efficiency between two-year and four-year institutions.
These agreements often aim both to increase transfer rates and baccalaureate degree completion
$\begin{array}{lr}\text { Journal website: http://epaa.asu.edu/ojs/ } & \text { Manuscript received: } 3 / 17 / 2020 \\ \text { Facebook: /EPAAA } & \text { Revisions received: } 12 / 1 / 2020 \\ \text { Twitter: @epa_aape } & \text { Accepted: } 2 / 2 / 2021\end{array}$ 
and to decrease time to degree. Studies exploring the efficacy of articulation agreements find that, despite being successful at decreasing the number of excess credits students earned at graduation and at increasing baccalaureate degree completion, these policies often increase time to degree. While there is considerable research on articulation agreements, few studies have examined the differential impact of these policies on students of Color who, prior literature has shown, experience barriers to realizing their baccalaureate degree aspirations. The purpose of this study was to examine whether the impact of North Carolina's statewide articulation agreement varied by a student's racial/ethnic identity when examining two-year post-transfer baccalaureate degree completion, time-to-degree completion, and excess credit accumulation. Keywords: community college; transfer; articulation agreement; historically underserved students; critical policy analysis

\section{¿Oportunidad para todos? Los impactos diferenciales del acuerdo de articulación integral revisado de North Carolina por raza / etnia}

Resumen: Los acuerdos de articulación de transferencia son empleados por instituciones de educación superior y legislaturas estatales para mejorar la eficiencia de la transferencia entre instituciones de dos y cuatro años. Estos convenios tienen como objetivo aumentar las tasas de transferencia y finalización de la licenciatura y disminuir el tiempo de graduación. Los estudios que exploran la efectividad de los acuerdos de enlace han encontrado que, aunque logran reducir el exceso de créditos obtenidos al graduarse y aumentar la finalización de las licenciaturas, estas políticas a menudo aumentan el tiempo de graduación. Pocos estudios han examinado el impacto diferencial de estas políticas en los estudiantes negros que enfrentan barreras para lograr sus aspiraciones de obtener una licenciatura. El propósito de este estudio fue examinar si el impacto del acuerdo de articulación del estado de North Carolina variaba según la identidad racial / étnica del estudiante al examinar la finalización de la licenciatura de dos años después de la transferencia, el tiempo para completar el curso y la acumulación. de exceso de crédito.

Keywords: colegio comunitario; transferir; acuerdo de articulación; estudiantes históricamente con poca asistencia; análisis crítico de políticas

\section{Oportunidade para todos? Os impactos diferenciais do acordo abrangente de articulação revisado da North Carolina por raça / etnia}

Resumo: Os acordos de articulação de transferência são empregados por instituições de ensino superior e legislaturas estaduais para melhorar a eficiência da transferência entre instituições de dois e quatro anos. Esses acordos têm como objetivo aumentar as taxas de transferência e conclusão do bacharelado e diminuir o tempo de graduação. Estudos que exploram a eficácia dos acordos de articulação descobriram que, apesar de serem bemsucedidos na redução dos créditos excedentes obtidos na graduação e no aumento da conclusão do bacharelado, essas políticas frequentemente aumentam o tempo de graduação. Poucos estudos examinaram o impacto diferencial dessas políticas sobre os alunos negros que enfrentam barreiras para realizar suas aspirações ao bacharelado. O objetivo deste estudo foi examinar se o impacto do acordo de articulação estadual da North Carolina variou de acordo com a identidade racial / étnica do aluno ao examinar a conclusão do bacharelado de dois anos após a transferência, o tempo para conclusão do curso e o acúmulo de crédito em excesso.

Palavras-chave: faculdade comunitária; transferir; acordo de articulação; alunos historicamente mal atendidos; análise crítica da política 


\section{Introduction}

Earning a baccalaureate degree remains one of the most promising pathways to economic stability (Carnevale et al., 2011; Ma et al., 2019). Recent estimates indicate that those with a baccalaureate degree earn up to $\$ 15,000$ more annually (U.S. Census Bureau, 2019a) and 31\% more over their lifetime (Carnevale et al., 2011) than those with an associate degree. Although the traditional pathway to a baccalaureate degree involves direct enrollment in a four-year institution, community college transfer is a popular option for students who intend to earn a four-year degree (Shapiro et al., 2017). The community college transfer pathway may be especially prominent among traditionally underserved student populations (e.g., minoritized racial/ethnic groups) who are more likely to access postsecondary education through community colleges (Goldrick-Rab, 2010).

While transfer from community colleges to four-year institutions is crucial in facilitating economic mobility for many individuals, students who begin postsecondary enrollment at the community college are significantly less likely to earn a baccalaureate degree compared to their counterparts that begin at a four-year institution (Alfonso, 2006; Doyle, 2009; Long \& Kurlaender, 2009; Monaghan \& Atwell, 2015). In addition, there is evidence that some student groups, particularly those identifying as Black and Latinx, experience greater barriers to realizing their baccalaureate degree aspirations compared to their White counterparts. Previous research indicates that Black and Latinx students are less likely than White students to transfer and earn baccalaureate degrees upon transfer (Hoachlander et al., 2003; Shapiro et al., 2018). To address inefficiency in transfer, policymakers in multiple states have recently enacted statewide articulation legislation, which governs and structures transfer between community colleges and four-year institutions (O’Meara et al., 2007).

This study examined one such significant policy change, North Carolina's Comprehensive Articulation Agreement (CAA). Specifically, in 2014, the North Carolina General Assembly enacted revisions to the state's existing articulation agreement between the North Carolina Community College System (NCCCS) and the University of North Carolina (UNC) System. This revised CAA guarantees 60 transferable credits to all NCCCS students who complete an Associate in Arts (AA) or Associate in Science (AS) degree, assures junior status at the UNC System transfer institution, requires UNC System institutions to publish baccalaureate degree plans online, and assures that students who complete CAA-qualifying degrees will gain admission into at least one public four-year institution with waivers for all general education requirements at the accepting institution. The goal of the CAA revision was to "Optimize the transfer of credits" (UNC System \& NCCCS, 2014, p. 1), resulting in less excess credit accumulation, a decrease in time to degree, and, ultimately, an increase in the likelihood of baccalaureate degree completion among students who transfer from North Carolina's community colleges to its public four-year institutions.

However, recent research on the efficacy of articulation agreements in addressing transfer efficiency is mixed. While some studies indicate that articulation agreements similar to the CAA were successful in decreasing the number of excess credits students earned at graduation (Baker, 2016) and in increasing rates of baccalaureate degree completion (Stern, 2016), others have found that these policies increase time to degree (Boatman \& Soliz, 2018). Stern and Baker agree that the positive outcomes observed in their studies (increased baccalaureate degree completion and reduced excess credits at graduation, respectively) were a result of highly structured transfer pathways that ensure credit efficiency and transferability. Conversely, Boatman and Soliz point to their finding that students transferring under the articulation agreement in their study spent, on average, a semester longer enrolled at the four-year college as evidence that these policies may not increase credit efficiency enough to promote faster movement toward graduation. While useful in exploring the 
efficacy of articulation agreements in general, this body of work does not consider the differential impact that articulation agreements can have on students representing diverse background characteristics. Specifically, prior research suggests that students of Color may experience barriers as they navigate the transfer process. Students of Color are less likely to transfer than are White students (Hoachlander et al., 2003; Shapiro et al., 2018), they tend to lose more credits during the transfer process (Giani, 2019), and therefore they accumulate greater numbers of excess credits prior to graduation (Fink et al., 2018). These findings suggest that students of Color face disparate transfer experiences.

This study applied a critical policy analysis (CPA) approach to understand the consequences of articulation agreements for traditionally underserved racial/ethnic groups, using the revised CAA in North Carolina as an example (Allan et al., 2010). CPA tasks researchers with identifying "policy 'winners' and 'losers"' and understanding "the broader effect a given policy has on relationships of inequality and privilege" (Diem et al., 2014, p. 843) by exploring heterogeneous effects of policy on historically marginalized groups. Regarding the CAA in North Carolina, there is no specific mention of race anywhere in the policy itself or in any associated accountability measures. Yet, prior literature on traditionally underserved students' college experiences indicates that these populations are often not privy to the resources that provide the knowledge necessary to adhere to such policies (Dynarski \& Scott-Clayton, 2006; Perna, 2006). In light of this and in order to inform more equitable policies in the future, it is important to understand whether certain racial/ethnic groups benefit from the policy more than do others (Bensimon, 2020). To understand the impact of the 2014 CAA revisions by race/ethnicity, we applied quasi-experimental techniques, specifically difference-in-differences, to answer the following research questions:

1. Does the impact of the CAA on two-year baccalaureate completion rates vary by race/ethnicity?

2. Does the impact of the CAA on time to baccalaureate degree vary by race/ethnicity?

3. Does the impact of the CAA on excess credit accumulation at baccalaureate degree completion vary by race/ethnicity?

\section{Literature Review}

This study was motivated, in part, by the diverse racial and ethnic profiles of students who participate in the United States' postsecondary system, both at two- and four-year institutions. Nationally, the proportion of the population identifying as White is much larger compared to individuals enrolled at both community colleges and public universities (National Center for Education Statistics, n.d.; US Census Bureau, 2019b; see Table 1). When comparing across higher education sectors, the proportions of Black and Latinx individuals are much more comparable, though, with the exception of Latinx individuals who, collectively, make up one fourth of the total population of community colleges. Thus, the institutional systems that comprise U.S. higher education are, generally, much more racially diverse than is the country. A similar picture emerges when exploring demographic data from North Carolina (US Census Bureau, 2019c) (see Table 2). As with the national statistics, the proportions of Black and Latinx individuals are comparable across all three populations, but the state has a much higher proportion of White individuals (NCCCS, 2019; UNC System, 2020). 


\section{Table 1}

National College Enrollment by Race

\begin{tabular}{lccc}
\hline Category & \multicolumn{3}{c}{ Racial/Ethnic Composition } \\
\hline \multirow{2}{*}{ Nation } & Black & Latinx & White \\
\cline { 2 - 4 } Community & $15 \%$ & $18 \%$ & $74 \%$ \\
College & $13 \%$ & $25 \%$ & $49 \%$ \\
Public 4-Year & $11 \%$ & $17 \%$ & $55 \%$ \\
\hline
\end{tabular}

\section{Table 2}

North Carolina College Enrollment by Race

\begin{tabular}{lccc}
\hline Category & \multicolumn{3}{c}{ Racial/Ethnic Composition } \\
\hline & Black & Latinx & White \\
\cline { 2 - 4 } State & $22 \%$ & $10 \%$ & $71 \%$ \\
Community & $21 \%$ & $10 \%$ & $57 \%$ \\
College & $20 \%$ & $7 \%$ & $56 \%$ \\
Public 4-Year & & & \\
\hline
\end{tabular}

Such diversity in access to higher education institutions is important, as postsecondary credentials, particularly the baccalaureate degree, open the door to much greater earnings potential and are essential for the $21 \mathrm{st}$-century labor market (Carnevale, et al., 2016). The increased earnings potential associated with additional education may be especially important for students from historically marginalized backgrounds who face systemic barriers to intergenerational wealth and often rely on postsecondary education for economic mobility (Hamilton \& Darity, 2010; McIntosh et al., 2020). Specifically, baccalaureate degree earners accumulate $31 \%$ (or $\$ 500,000$ ) more in lifetime earnings than do associate degree earners (Carnevale et al., 2011). The wage difference between baccalaureate degree earners and high school diploma earners is even more staggering at almost $\$ 1$ million in lifetime earnings (Carnevale et al., 2011). Thus, for students who begin their educational journeys at the community college, successful and efficient transfer processes are essential to access the increased earnings potential that postsecondary education can offer.

Unfortunately, the community-college-to-baccalaureate-degree path has proven quite difficult to complete. As demonstrated through research by Shapiro and associates (2017), less than half $(42 \%)$ of all community college transfer students end up earning a baccalaureate degree; and, lamentably, only $13 \%$ of all students who begin their higher education journeys at community colleges ever earn a baccalaureate degree. These low success rates can be explained by the complexity of the transfer process (Taylor, 2019) and the associated, all-too-common credit loss that occurs when moving from the community college to the university (Xu et al., 2018).

\section{Research on Articulation Agreements}

As a potential alleviating force to demystify complexity and reduce credit loss, policymakers and educators have organized formal articulation agreements (often through legislation) that have broad, sweeping powers over the ways by which students transfer among multiple public institutions. Such agreements governing the transfer of credits between community colleges and universities have been employed since the 1970s when Florida, Georgia, Illinois, and Texas each independently developed their own (O’Meara et al., 2007). Other states followed suit; and today, to 
differing degrees, every state has some form of articulation agreement between their community colleges and universities (Ignash \& Townsend, 2000; O’Meara et al., 2007; WICHE, 2010). Articulation agreements vary across states and institutions, but are typically either (1) $2+2$ systems (where students meet all general education and pre-major requirements at the community college prior to transfer into any program at any university), (2) credit equivalency systems (where pre-major requirements may vary from university to university), or (3) institution-driven systems (where premajor choices vary depending on both the university and the program of study; Hodara et al., 2017).

The purpose of these agreements is to improve transfer efficiency between two-year and four-year institutions by increasing transfer rates and baccalaureate degree completion and by decreasing time to degree. As mentioned earlier, along these lines, the stated purpose of North Carolina's CAA is to "optimize the transfer of credits" (UNC System \& NCCCS, 2014, p. 1) between the University of North Carolina (UNC) System and the North Carolina Community College System (NCCCS), the two public systems of higher education in North Carolina. Within North Carolina's framework for articulation and transfer, the CAA is intended to serve all students and functions under an institution-driven system (Hodara et al., 2017)—one where each institution publishes and advertises the specific required courses necessary to be taken for each specific program of study prior to transfer.

The CAA was originally designed to ease the transfer process by "simplifying further the transfer of credits for students and thus facilitating their educational progress as they pursue associate or baccalaureate degrees within and among public post-secondary institutions in North Carolina" (UNC System \& NCCCS, 1997, p. 1). Joint efforts by individuals within both public systems of higher education, in concert with the North Carolina legislature, resulted in an articulation agreement with a common general education transfer core, more regulated AA and AS degrees, and a transfer information system that would allow for electronic transmission of data between the two public institution systems (UNC System \& NCCCS, 1997).

However, the CAA did not always function as originally intended (MGT of America, 2004). In fact, it took ten years after noted deficiencies in the original version of the CAA were presented by an outside consulting group (MGT of America, 2004) before these issues were addressed through legislation with the revised version in 2014. Finally, in that year, the policy underwent legislativelymandated, significant revision designed to address the shortcomings in the original version that were highlighted by the consulting firm through the requiring of the publication of four-year degree plans, through the guaranteeing of course-for-course transfer of general education credits, and through the guaranteeing of admission to at least one UNC System university upon completion of either the AA or AS degree at the community college. The length of time between the notification of the needed revisions and the actual legislation that accomplished those changes demonstrates the power that state legislatures can hold in the development and efficacy of institution-driven articulation agreements. Regardless, representatives from both the UNC System and the NCCCS jointly presented to the state legislature that their objective in this revised agreement was to help more students graduate in less time with fewer credits.

Unfortunately, the explicitly stated intentions of statewide articulation agreements, like the one implemented in North Carolina, do not always match the results. For instance, prior studies have demonstrated mixed results when examining the outcomes of transfer rates (Anderson et al., 2006; Higgins \& Kastinas, 1999; King, 2019, Roksa, 2006; Stern 2016), baccalaureate degree completion (Baker, 2016; Roksa \& Keith, 2008; Stern, 2016), and time to degree (Roksa \& Keith, 2008). Thus, the possibility remains that articulation agreements may not be helping students as much as policymakers might hope.

Specifically, while Higgins and Katsinas (1999) initially found an increased likelihood of transfer among states with mandated articulation agreements, more recent studies (Anderson et al., 
2006; King, 2019; Roksa, 2006; Stern, 2016) have demonstrated no such impact. Even so, Stern's research indicated higher percentages of baccalaureate degree completion among states with articulation agreements. These apparent contradictory findings may be explained best by understanding articulation agreements as aids in the efficiency of transfer for those who elect to do so rather than as instigators of transfer for those who never had any intent to earn a baccalaureate degree (Roksa \& Keith, 2008).

In addition to stimulating transfer and baccalaureate degree completion, articulation agreements are also intended to reduce how long it takes a student to complete a degree. In research on time to degree, Xu et al. (2018) discovered that community college transfer students take two (2) more semesters to graduate, on average, than do students who begin and end their baccalaureate degree journeys at the university. Moreover, Boatman and Soliz (2018) found that articulation agreements actually increase the time required for community college transfer students to earn a baccalaureate degree. Specifically, students abiding by the tenets of the statewide articulation agreement in Ohio spend, on average, almost one (1) more full term enrolled to earn their degree than those who begin and end at the university. (Boatman and Soliz do note that this extra time is spent at the community college prior to transfer rather than at the university after transfer.)

A key factor in the time it takes to earn a baccalaureate degree is the amount of excess credits (i.e., credits in excess of the requirement for a baccalaureate degree, typically 120) that a student might accumulate over their educational journey. While the knowledge gained from a course not needed for graduation may be beneficial to the student in more abstract ways, each course taken that does not directly contribute to the earning of a baccalaureate degree results in extra time (Fink et al., 2018) and money (Kramer et al., 2018; Ziedenberg, 2015) to the overall cost of education. Students who take the transfer path from a community college to a university experience such excess credit accumulation disproportionately from those who start and end at a university (Fink et al., 2018). Specifically, those students who begin at the community college take 10 more credits prior to graduation, on average, than do those who start at the university (Fink et al., 2018). Fortunately, one recent study in California has demonstrated that specific transfer degrees that are part of articulation agreements can be successful in reducing the number of excess credits accumulated (Baker, 2016).

\section{Students of Color and Community College Transfer}

Unfortunately, not all students may benefit equally from policies like North Carolina's revised CAA. As has been the case for many years, students of differing demographic and academic backgrounds experience the U.S. education system differently (Chang, 2003; Harris \& BrckaLorenz, 2017; Rankin \& Reason, 2005). A recent equity report published by the NCCCS provides data detailing the outcomes and performance measures of each racial/ethnic population in their educational journeys within the state's community college system. For instance, according to the report, each of the racial/ethnic populations in our study are enrolled about equally in transfer programs at the community college (e.g., the AA or AS degree programs); i.e., $41 \%$ of Black students, $45 \%$ of Latinx students, and $48 \%$ of White students are enrolled in programs designed to transfer (NCCCS, 2019). Yet, despite these similar intentions to transfer, Black students experience barriers to successful completion of college-level mathematics and English courses within their first year of enrollment that do not seem to be present for their White and Latinx counterparts (NCCCS, 2019), a trend that leads to lower rates of retention and degree completion, much less transfer (Complete College America, 2020). Additional evidence of these barriers to success is found among first-year indicators of satisfactory academic progress (SAP), which are lower among Black students compared to students identifying with other demographic groups (NCCCS, 2019). (SAP is defined as earning a GPA of greater than or equal to 2.00 and completing $67 \%$ of credits attempted.) These trends indicate that students of Color are not being adequately supported by the institutions of 
higher education in which they are enrolled. Additionally, these latter facts (see Table 3) inherently reduce the chances of Black students transferring and likely lead to the greater number of excess credits accumulated in their academic journeys.

Table 3

Completion Rates for North Carolina Community College System Students During First Year

\begin{tabular}{lccc}
\hline NC Community College Student & CL Math & CL English & SAP \\
\hline Black students & $17 \%$ & $44 \%$ & $34 \%$ \\
Hispanic or Latino students & $32 \%$ & $62 \%$ & $50 \%$ \\
White students & $38 \%$ & $67 \%$ & $57 \%$ \\
Total & $33 \%$ & $61 \%$ & $50 \%$ \\
\hline Note: Adapted from 2019 Equity Report: Identifying Access and Academic Process Gaps in the North Carolina \\
Community College System
\end{tabular}

In light of the evidence that students of Color face systemic barriers to academic success at community colleges, it is important to consider how articulation agreements differentially impact students by race/ethnicity, above and beyond other factors (e.g., availability of financial aid and the presence or absence of social support) that contribute or detract from student success. Multiple studies have found that, likely due to similar barriers, students of Color are less likely to transfer from the community college to a four-year institution than are White students (Hoachlander et al., 2003; Shapiro et al., 2018). According to Hoachlander and associates' research, only 6\% of students of Color who begin at a community college actually earn a baccalaureate degree within six (6) years. Thus, under these conditions, transfer fulfills a stratifying function (Chase et al., 2014) by typically permitting one group of students - in this case, White students from higher socioeconomic backgrounds - to access higher credentials in ways that students of Color are not afforded. Our study is not the first to explore policy-induced community college student outcomes differentiated by racial/ethnic identity. In a recent study, Kosiewicz and Ngo (2020) found that when students self-placed into mathematics courses (as opposed to taking a placement test or to being placed through other measures), outcomes such as completion of transferable mathematics courses improved for White students but not for Black or Latinx students.

Initial evidence on equitable excess-credit and time-to-degree outcomes is, unfortunately, not too promising. Fink and colleagues (2018) discovered that Black students often attempt greater numbers of excess credits in their educational journeys than do their White counterparts. Furthermore, Giani (2019) found that while all transfer students in North Carolina lose an average of $7.2 \%$ of their earned community college credits when they matriculate to a state university, "students of Color were significantly more likely to experience credit loss compared to White students" (p. 24). Each of these studies reveal the disparate outcomes that are likely to be experienced by students of Color. This is of particular concern because the only differentiating variable between these students in a comparison of their disparate educational experiences is the racial/ethnic group with which they identify. Furthermore, while identifying the existence of racial disparities is quite straightforward, as we demonstrate later in this paper, determining whether these disparities arise from discriminatory processes is much more complex (Mickelson, 2003).

Despite clear evidence that students of Color experience barriers in the transfer process, most state articulation policy does not specifically mention race nor does it provide transfer-related accountability measures (Chase et al., 2014). Thus, no provisions are made to ease the transfer process for populations that may experience transfer in disproportionate ways. This is also the case 
in North Carolina, as there is no specific mention of racial/ethnic groups anywhere in the articulation policy. Additionally, the literature available on the efficacy of articulation agreements has only addressed race as a covariate. In this way, race has not been centered in the conversation around the efficacy of statewide articulation agreements. Our study attempts to fill this gap by exploring whether likelihood of completion, time to degree, and excess credits vary across racial/ethnic groups.

\section{Conceptual Framework}

Given the importance of community college transfer in the educational and economic success of a diverse student population, we relied on Critical Policy Analysis (CPA) to guide the scope of this study. CPA seeks to "illuminate the ways in which power operates through policy by drawing attention to hidden assumptions or policy silences and unintended consequences of policy practices" (Allan, et al., 2010, p. 24). CPA focuses on six (6) concerns:

(1) [The] difference between policy rhetoric and practiced reality...; (2) [the] distribution of power, resources, and knowledge...; (3) policy 'winners' and 'losers'...; (4) policy roots and development...; (5) [the] nature of resistance to or engagement in policy by members of non-dominant groups...; [and] (6) social stratification and the broader effect a given policy has on relationships of inequality and privilege. (Diem et al., 2014, p. 843)

When used as a framework, CPA guides how the researcher formulates research questions, interprets results, and provides suggestions for changes to policy and practice (Heck, 2004). While qualitative methodology is more common in studies framed by CPA, quantitative scholars have engaged with CPA by using "data to represent educational processes and outcomes on a large scale to reveal inequities and to identify social or institutional perpetuation of systemic inequities in such processes and outcomes" (Stage, 2007, p. 10). To maintain the critical nature of CPA, quantitative applications of this framework should seek to center issues surrounding systemic oppression, recognize that numbers are not neutral and can promote deficit narratives, and work to contextualize statistical analyses using qualitative research (Garcia et al., 2018; Gillborn et al., 2018).

This study, like many quantitative applications of CPA (Chase, 2011, 2014; Parekh \& Brown, 2018; Tabron \& Ramlackhan, 2019) sought to explore heterogeneous effects of policy for historically marginalized groups, specifically those belonging to minoritized racial/ethnic groups. In particular, we drew on CPA to focus our research questions on identifying the disparate effects of the CAA by race/ethnicity, inform our choice to disaggregate our data, drive our decision to include qualitative research to contextualize our findings, and center the role of educational policies and systems in our suggestions for changes to policy and practice. In doing so, we engaged in several of CPA's six concerns including "[The] difference between policy rhetoric and practiced reality...; policy roots and development..; [the] distribution of power, resources, and knowledge...; policy 'winners' and 'losers'...; [and] social stratification and the broader effect a given policy has on relationships of inequality and privilege" (Diem et al., 2014, p. 843).

As mentioned earlier, guiding the formulation of research questions is one of CPA's express purposes. In particular, CPA's focus on "[the] difference between policy rhetoric and practiced reality" and "policy roots and development" informed the thrust of this study. As described above, the CAA revisions were intended to ease the transfer process for all students enrolled in qualifying majors; however, previously cited literature on race/ethnicity and transfer indicates that existing policies and systems may disadvantage students of Color in the transfer process. Despite this, mention of race/ethnicity in the policy or accountability measures is conspicuously missing, making 
the CAA revision, like many other articulation agreements, silent on the issue of race (Chase et al., 2014). Policymakers' decision to develop the CAA without including measures that address race/ethnicity may invite a scenario wherein the policy benefits White students more than students of Color, making the policy rhetoric emphasizing transfer success for all difficult to realize.

The CAA's "roots and development" as a policy that does not speak explicitly to issues of race, in light of literature that demonstrates that students of Color face barriers in the transfer process, indicates that we may observe a difference between "policy rhetoric and practiced reality" (Diem et al., 2014, p. 843). Therefore, it is important both to explore whether the CAA reinforces existing stratification across racial/ethnic groups and to identify which racial/ethnic groups benefit most and least from the policy ("policy 'winners' and 'losers"; Diem et al., 2014, p. 843). While much of the research around equity and transfer has focused on differential outcomes by race/ethnicity, very few scholars that have studied articulation agreements have focused on race/ethnicity in their analyses. In light of this gap in the research and in keeping with the tenets of $\mathrm{CPA}$ and critical quantitative analyses, we chose to center race/ethnicity as we formulated our research questions. In addition, our research design disaggregated data by racial/ethnic group. This methodological choice not only recognizes the historically uneven distribution of structural support and opportunity among students from different racial/ethnic groups (Teranishi, 2007), but also allowed us to identify whether the CAA perpetuates systemic inequality in the community college transfer process and for whom (Stage, 2007).

In addition to guiding how we focused this study and analyzed our data, CPA informed our discussion of results and our proposed changes to policy and practice. In our discussion, we drew on qualitative research to contextualize our findings (Garcia et al., 2018; Gillborn et al., 2018) and considered how "[the] distribution of power, resources, and knowledge" may drive the differential effects of the CAA on transfer outcomes. Furthermore, we emphasized the role of institutions and policy as drivers of inequity and were careful not to perpetuate deficit narratives that blame marginalized students for their own outcomes (Garcia et al., 2018; Gillborn et al., 2018). Finally, we centered the responsibility of institutions and policymakers to ensure equity as we proposed changes to policy and practice.

\section{Method}

To evaluate the impact of the CAA revisions on three academic outcomes, namely two-year completion, time to degree, and excess credit accumulation, for students representing different racial/ethnic backgrounds, we relied on a difference-in-differences (DID) analytic approach. While the majority of CPA work utilizes qualitative methodologies, quantitative applications of critical frameworks allow researchers to reveal the relationship between policies, institutions, and inequities on a large scale (Stage, 2007). Our methodology, DID, is particularly well suited for this task, as it allowed us to utilize observational data to isolate and estimate the impact of the CAA revision on key transfer outcomes, as well as determine whether the impact varied across racial/ethnic groups.

In keeping with the tenets of CPA and critical quantitative analyses, we conducted our analyses on disaggregated data, meaning that we studied the impact of the CAA revisions on each racial/ethnic group individually rather than aggregating data and controlling for race/ethnicity in our analyses. Such data disaggregation is an important component of critical quantitative analysis as it allows for each racial/ethnic group to be represented in its own right, acknowledging the historically uneven distribution of resources and opportunities among students from different backgrounds (Teranishi, 2007). For our purposes, we conducted separate DID analyses for three racial/ethnic groups: Black, Latinx, and White. These students represent the largest racial/ethnic demographic 
groups in North Carolina (US Census Bureau, 2019c) and, practically speaking, were the groups for which we had sufficient data to conduct statistical analyses. However, we acknowledge that additional racial/ethnic groups, such as Asian and Native American students, are represented in the population in North Carolina, and our results may not apply to these groups. Regardless, our use of DID begins to illuminate CAA "winners' and 'losers" and the effects the CAA "has on relationships of inequality and privilege" (Diem et al., 2014, p. 843).

DID takes advantage of the fact that, while the CAA revisions were not randomly assigned to students, outcomes of students in the treatment (those students who earned an AA or an AS degree prior to transfer) and control (those students who did not earn an AA or an AS degree prior to transfer) groups moved in parallel prior to the revisions (Angrist \& Pischke, 2015). Indeed, these parallel trends in the pre-treatment time period represent a key assumption of DID analysis and are discussed in depth in the Analysis section below. In applying this analytic approach, we were able to take advantage of the natural experimental context of the CAA revisions, meaning that these revisions created "natural" treatment and control groups over time, to estimate the causal impact of the policy change on students' outcomes (Cunningham, 2018; Greene, 2012). Recent work has utilized DID to understand the effects of policy on the outcomes of community college students. Like our study, the authors centered race in their analyses to understand whether the effects of the policy varied for different racial groups (Kosiewicz \& Ngo, 2020). The technical aspects of DID are discussed in detail below; but, in brief, a DID estimate $(E)$ simply subtracts two differences: The first difference subtracts the pre-policy implementation outcome from the post-policy implementation outcome of the treatment group, while the second difference does the same for the control group (Greene, 2012), as in (1):

$$
E=\left[\left(\bar{y}_{\text {post } \backslash \text { treatment }}\right)-\left(\bar{y}_{\text {pre } \backslash \text { treatment }}\right)\right]-\left[\left(\bar{y}_{\text {post } \backslash \text { control }}\right)-\left(\bar{y}_{\text {pre } \backslash \text { control }}\right)\right](1)
$$

In subtracting these differences, DID allows researchers to use pre-treatment time trends on the outcomes of interest to estimate what would have happened to the treatment group in the absence of treatment (the CAA revisions, in our case) (Angrist \& Pischke, 2015). In a regression context, described below, the researcher can also incorporate theoretically-derived covariates into a DID analysis.

\section{Data}

We derived variables for this study from a dataset provided by the administrative office of the University of North Carolina System. This dataset is organized in a rolling cross-sectional format, spanning eight (8) academic years (Fall 2010 to Summer 2019), and included all students who transferred from one of North Carolina's community colleges to one of its public four-year institutions during this time period $(N=98,444)$. We took analytic sub-samples of this dataset to accommodate our outcomes of interest. We first removed from our dataset any students who had earned only a certificate or a diploma from the community college prior to transfer $(N=2,211)$. We made this decision because these types of credential programs are typically not intended for transfer, and there were very few students who earned these credentials in our dataset. In our sample, we kept those students who had earned an AA or an AS degree, any other type of associate degree (e.g., AFA, AAS, AGE, etc.), or no degree at all. To evaluate both excess credits and time to degree, we limited the dataset to only those students who completed a baccalaureate degree during the observational period of our study, as these variables are only valid for degree completers. To evaluate two-year completion, we limited the dataset to academic years beginning in Fall 2010 to Fall 2017 to allow students two (2) years to complete a baccalaureate degree post-transfer. 
In limiting our dataset in these ways, we were concerned that the ratio between students who graduated and those who did not would differ by racial/ethnic group, which would have the potential to bias our results. We observed that $59 \%$ of White students in our sample graduated while $69 \%$ and $65 \%$ of Black and Latinx students graduated, respectively. These student success patterns are echoed in the data on persistence rates in North Carolina, as the differences in one-year persistence rates (remaining enrolled after one (1) year at the university) between Black (83\%), Latinx (84\%), and White (87\%) students are quite small (NCCCS, 2020). Given that success rates for both graduation and persistence do not differ substantially by race/ethnicity, we do not believe that limiting our dataset to only graduates biases our results. In Table 4, we provide the numbers of students belonging to each of our subsamples by racial/ethnic group.

\section{Table 4}

\begin{tabular}{lccr} 
Proportion of Graduates to Non-Graduates by Race & \\
\hline Race & $\%$ Graduated & \% Not Graduated & \multicolumn{1}{c}{ N } \\
\hline Black & 69 & 31 & 14,700 \\
Latinx & 65 & 35 & 6,555 \\
White & 59 & 41 & 56,156 \\
\hline
\end{tabular}

\section{Variables}

The variables we used in this study fall into four groups: policy implementation, treatment groups, outcomes, and covariates.

Policy implementation. Policy implementation refers to the temporal component of our dataset and is a binary variable representing one of two time periods, defined in the term that a student transferred to the four-year institution. For our purposes, we defined policy implementation as occurring in Fall 2014, the first term that students were able to take advantage of the provisions provided in the revised CAA. Observations from students who transferred before Fall 2014 were assigned to the pre-treatment time period while observations from students who transferred after Fall 2014 were assigned to the post-treatment time period. To explore the potential for a delayed treatment effect, meaning that students took some time to take full advantage of the CAA revisions, we duplicated this policy implementation variable to accommodate a pre-treatment period that occurred prior to Fall 2016, while the post-treatment period was defined as Fall 2016 or later. A delayed treatment effect is very possible in a situation where treatment refers to policy revisions that require students both to obtain information about the revisions and also to alter their credentialseeking behavior accordingly. Thus, while students were technically able to take advantage of the CAA revisions in Fall 2014, they were not necessarily aware of the revisions prior to this term and thus may not have been able to take full advantage of the CAA provisions.

Treatment groups. As already mentioned, our treatment and control groups were defined according to the degree (if any) that students earned at the community college prior to transfer. Students who earned an AA or an AS degree prior to transfer were the focus of the CAA revisions and thus comprised our treatment group. Students who did not earn an AA or an AS degree prior to transfer, while able to take advantage of some of the CAA revisions, were not the focus of this policy and thus comprised our control group.

Outcomes. We explored three outcomes that represent different aspects of transfer student success regarding baccalaureate degree completion. Our first outcome of interest was baccalaureate degree completion within two years of transferring, coded as a binary variable $(1=$ completed within two years, $0=$ did not complete within two years). This outcome was calculated by counting the 
number of terms a student enrolled at the four-year institution after transferring. To count terms, we split academic years into three parts (fall, spring, and summer), with each term counting as a unique term of enrollment. A student was counted as completing within two years (" 1 ") if they graduated in six (6) or fewer consecutive terms. For example, if a student first enrolled at the four-year university in Fall 2010 and then graduated in Spring 2012, this student would receive a "1" because five (5) consecutive semesters would have passed between initial enrollment and graduation. If a student did not graduate within six (6) or fewer consecutive terms at the four-year institution, they were counted as not completing within two years ("O").

Our second outcome of interest was time to degree. For this variable, we counted the number of consecutive terms that a student was enrolled at the four-year institution, as just described. That is, we divided the academic year into three parts (fall, spring, and summer) and counted each term of potential enrollment. Like excess credits, this variable is valid only for students who completed their degrees, as there is a non-zero probability that students who did not complete a degree within our observational period would have continued enrollment (or re-enrolled) at the four-year institution and subsequently completed a degree, thus invalidating a time-to-degree calculation.

Our third and final outcome of interest was excess credits. We defined this outcome as the number of credit hours that a student had earned at the time of degree completion in excess of 120, the typical number of hours required for a baccalaureate degree. Consequently, this variable is valid only for students who completed a baccalaureate degree. We calculated this variable by subtracting 120 from the total number of hours that a student had earned at graduation. Students with a value of 0 for this variable earned exactly 120 hours, while those with a value greater than 0 had earned that specific number of excess credits. Because this variable was positively skewed toward 0 , our analyses focused on the logged value of this outcome.

Covariates. The final category of variables that we included in our study were covariates. These variables were derived from prior literature and account for changes in the composition of our treatment and control groups over time. Demographic covariates included gender identity, whether a student transferred from a rural community (as defined by the U.S. Census Bureau), and socioeconomic status (using federal Pell Grant status in their last semester of enrollment as a proxy). Academic covariates consisted of whether a student earned International Baccalaureate (IB) or Advanced Placement (AP) credit in high school, whether a student majored in a science, technology, engineering, or math (STEM) field ${ }^{1}$, whether the student was ever enrolled part-time during their time at the four-year institution, the number of times a student changed major fields of study, and the number of credits they transferred to the four-year university. Additionally, we included in our analyses a fixed effect corresponding to a student's two-to-four-year-institution pathway to account for any institution-to-institution articulation agreements or policies that may have affected our outcomes. Importantly, this group of variables did not include a student's racial/ethnic identity. Instead, as already explained, we disaggregated data by race/ethnicity to estimate the impact of the CAA on students' outcomes. This disaggregation acknowledges that the policy may have had differential impacts on students depending on their racial/ethnic identification, resulting from historical inequities in access to key resources that contribute to student success (Teranishi, 2007). See Table 5 for descriptive statistics.

1 To construct this variable, we used major classifications provided by the National Postsecondary Student Aid Study (National Center for Education Statistics, 2016). 


\section{Table 5}

Descriptive

Statistics

\begin{tabular}{|c|c|c|c|c|c|c|c|c|c|c|c|c|}
\hline \multirow[b]{3}{*}{ Variable } & \multicolumn{4}{|c|}{ White } & \multicolumn{4}{|c|}{ Black } & \multicolumn{4}{|c|}{ Latinx } \\
\hline & \multicolumn{2}{|c|}{ CAA } & \multicolumn{2}{|c|}{ No-CAA } & \multicolumn{2}{|c|}{ CAA } & \multicolumn{2}{|c|}{ No-CAA } & \multicolumn{2}{|c|}{ CAA } & \multicolumn{2}{|c|}{ No-CAA } \\
\hline & $\mathrm{M}$ & $\mathrm{SD}$ & $\mathrm{M}$ & SD & $\mathrm{M}$ & $\mathrm{SD}$ & $\mathrm{M}$ & $\mathrm{SD}$ & $\mathrm{M}$ & $\mathrm{SD}$ & $\mathrm{M}$ & $\mathrm{SD}$ \\
\hline $\begin{array}{l}\text { From a Rural } \\
\text { County } \\
\text { Received Pell }\end{array}$ & 0.28 & 0.45 & 0.28 & 0.45 & 0.17 & 0.37 & 0.18 & 0.39 & 0.19 & 0.39 & 0.16 & 0.37 \\
\hline Grant & 0.61 & 0.49 & 0.47 & 0.50 & 0.84 & 0.37 & 0.76 & 0.43 & 0.79 & 0.41 & 0.70 & 0.46 \\
\hline Female & 0.55 & 0.50 & 0.56 & 0.50 & 0.61 & 0.49 & 0.66 & 0.47 & 0.62 & 0.49 & 0.53 & 0.50 \\
\hline $\begin{array}{l}\text { STEM Major } \\
\text { Took AP/IB }\end{array}$ & 0.19 & 0.39 & 0.18 & 0.39 & 0.11 & 0.31 & 0.11 & 0.31 & 0.17 & 0.37 & 0.18 & 0.39 \\
\hline Course & 0.07 & 0.25 & 0.13 & 0.33 & 0.04 & 0.18 & 0.07 & 0.25 & 0.13 & 0.34 & 0.14 & 0.35 \\
\hline $\begin{array}{l}\text { Part Time } \\
\text { Major }\end{array}$ & 0.51 & 0.50 & 0.58 & 0.49 & 0.56 & 0.50 & 0.61 & 0.49 & 0.56 & 0.50 & 0.59 & 0.49 \\
\hline $\begin{array}{l}\text { Changes } \\
\text { Hours }\end{array}$ & 1.30 & 0.60 & 1.34 & 0.65 & 1.38 & 0.68 & 1.42 & 0.68 & 1.38 & 0.67 & 1.48 & 0.78 \\
\hline Transferred & 65.87 & 12.40 & 52.87 & 24.35 & 64.70 & 14.46 & 49.10 & 27.51 & 63.59 & 12.13 & 49.79 & 21.57 \\
\hline$N$ & & & & & & & & & & & & \\
\hline
\end{tabular}




\section{Analysis}

For each racial/ethnic group (Black, Latinx, and White) and for each outcome (two-year completion, time to degree, and excess credits), we first conducted the simple DID analysis described in (1), subtracting the differences in mean outcomes before and after policy implementation from one another for both the treatment and the control groups. We then conducted a more complex, regression-based DID model, as defined in (2), which allows for the inclusion of the covariates described in the previous section:

$$
Y_{i s t}=\beta_{1} \text { Post }+\beta_{2} \mathrm{CAA}+\beta_{3} \mathrm{CAA} \times \text { Post }+\gamma X_{i}+\lambda X_{s}+\varepsilon_{i s t}
$$

In (2), $Y_{\text {ist }}$ represents one of our outcomes of interest (two-year completion, time to degree, or excess credits) for student $i$ transferring to institution $s$ during term $t . \beta_{3}$, the coefficient of the interaction term CAA $\times$ Post, estimates the impact of the CAA revisions on the outcome and is the coefficient of interest in this study. $\gamma X_{i}$ represents covariates that apply to each individual student (e.g., demographic and academic characteristics), $\lambda X_{s}$ represents transfer pathway fixed effects, and $\varepsilon_{i s t}$ is an error term that we clustered at the four-year institution level. We conducted these analyses (summarized in equations 1 and 2) for each of our three outcomes and for each racial/ethnic group twice, once with policy implementation in 2014 and again with policy implementation in 2016, as already described. See Table 6 for a description of analyses and sample sizes.

\section{Table 6}

Description of Models

\begin{tabular}{|c|c|c|c|c|c|}
\hline Outcome Variable & Model & $\begin{array}{l}\text { Policy } \\
\text { Year }\end{array}$ & Data Subset & Race & $N$ \\
\hline \multirow{6}{*}{ Two-Year Completion } & 1 & 2014 & \multirow{6}{*}{$\begin{array}{l}\text { Fall 2010- Summer } \\
2017\end{array}$} & Black & \multirow{3}{*}{4,373} \\
\hline & 2 & 2016 & & Black & \\
\hline & 3 & 2014 & & Latinx & \\
\hline & 4 & 2016 & & Latinx & \multirow[t]{2}{*}{2,183} \\
\hline & 5 & 2014 & & White & \\
\hline & 6 & 2016 & & White & 22,359 \\
\hline \multirow{6}{*}{$\begin{array}{c}\text { Semester Count to } \\
\text { Graduation }\end{array}$} & 7 & 2014 & \multirow{6}{*}{$\begin{array}{l}\text { Fall 2010- Summer } \\
2018\end{array}$} & Black & \multirow{3}{*}{4,520} \\
\hline & 8 & 2016 & & Black & \\
\hline & 9 & 2014 & & Latinx & \\
\hline & 10 & 2016 & & Latinx & \multirow[t]{2}{*}{2,295} \\
\hline & 11 & 2014 & & White & \\
\hline & 12 & 2016 & & White & 23,230 \\
\hline \multirow{6}{*}{ Excess Credits } & 13 & 2014 & \multirow{6}{*}{$\begin{array}{l}\text { Fall 2010- Summer } \\
2018\end{array}$} & Black & \multirow[b]{2}{*}{4,530} \\
\hline & 14 & 2016 & & Black & \\
\hline & 15 & 2014 & & Latinx & \multirow{3}{*}{2,296} \\
\hline & 16 & 2016 & & Latinx & \\
\hline & 17 & 2014 & & White & \\
\hline & 18 & 201 & & White & 23,254 \\
\hline
\end{tabular}




\section{Parallel Trends Assumption}

As mentioned earlier, a key assumption of DID analysis is that the outcomes of the treatment and control groups moved in parallel over time in the pre-treatment time period (Angrist \& Pischke, 2015). The presence of such parallel trends indicates that the control group provides an adequate comparison group for the estimation of what would have happened to the treatment group in the counterfactual scenario wherein the treatment did not occur (i.e., had the CAA revisions not happened). To determine whether the parallel trends assumption was appropriate in our study, we visually inspected time trends for all three of our outcome variables for each racial/ethnic group, paying close attention to what happened in the pre-2014 and pre-2016 time periods. These time trends are displayed visually in Figures 1-3. The trends illustrated in these figures suggest that for all racial/ethnic groups and for all outcomes, the parallel trends assumption was met.

\section{Figure 1}

\section{Parallel Trends Plots for 2-Year Completion}



Note: Students in this plot are Black.

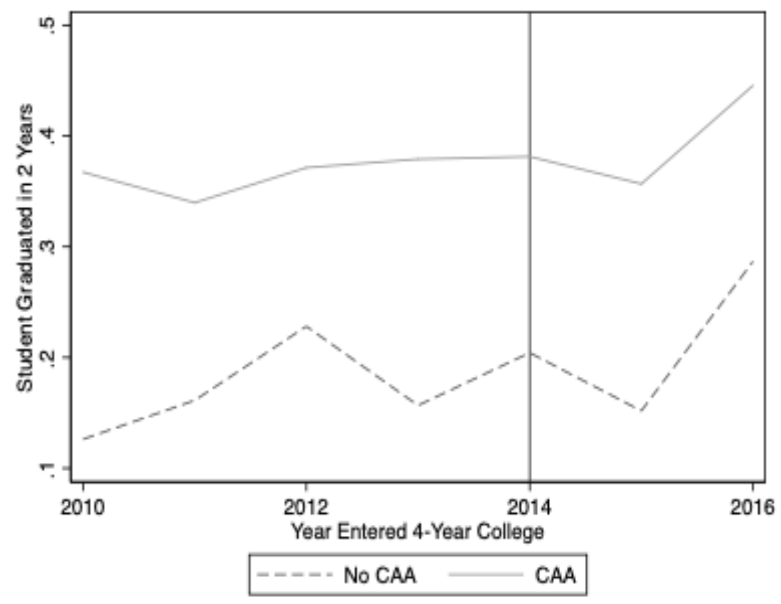

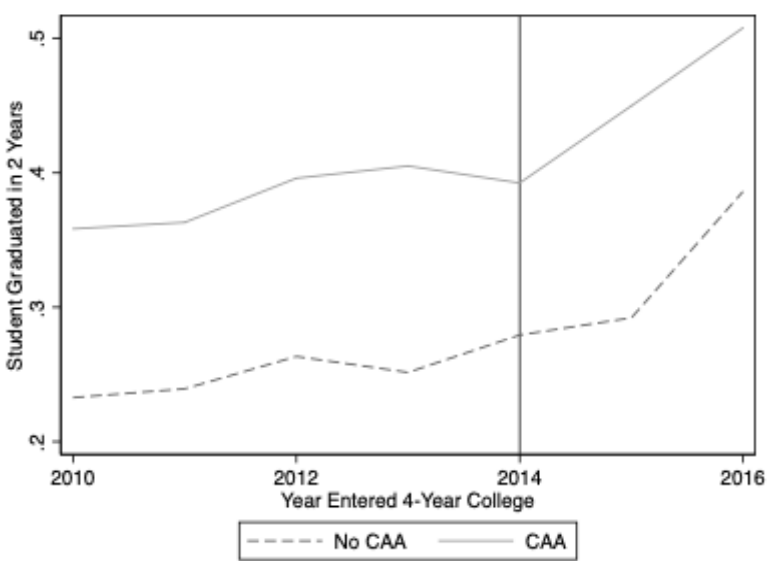

Note: Students in this plot are White

Note: Students in this plot are Latinx 


\section{Figure 2}

Parallel Trends Plots for Semester Count to Graduation

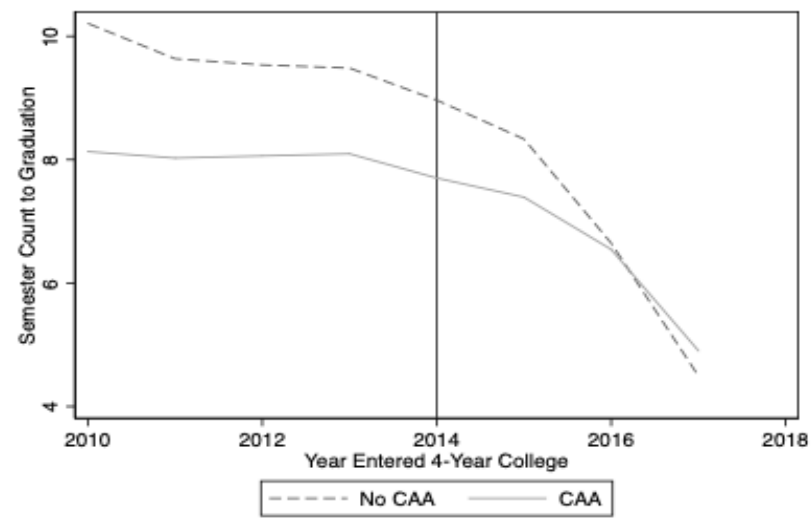

Note: Students in this plot are Black

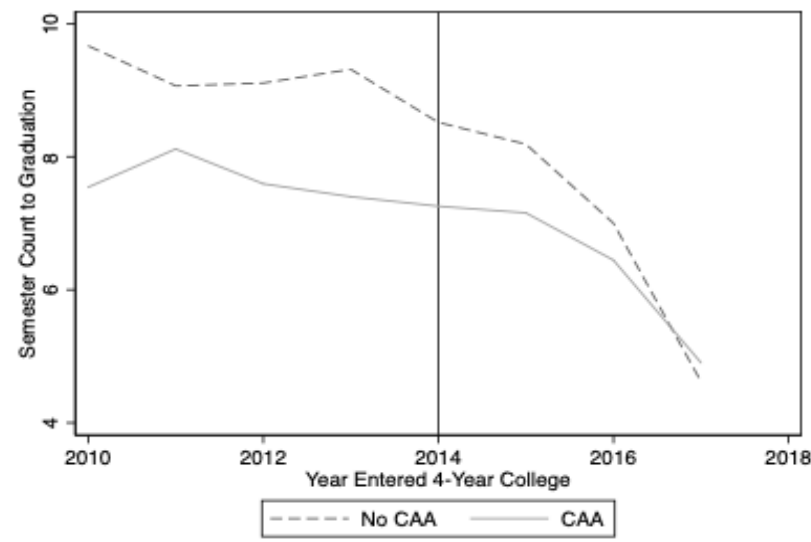

Note: Students in this plot are Latinx

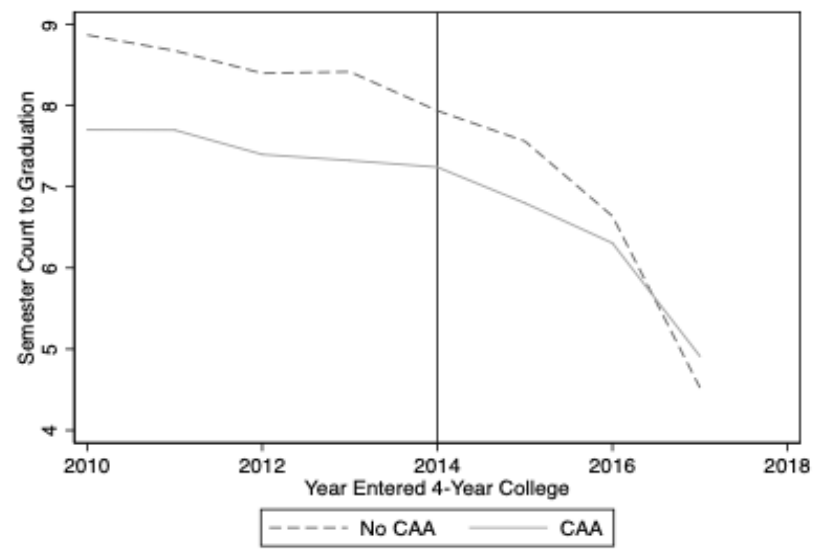

Note: Students in this plot are White 


\section{Figure 3}

Parallel Trends Plots for Excess Credits past 120

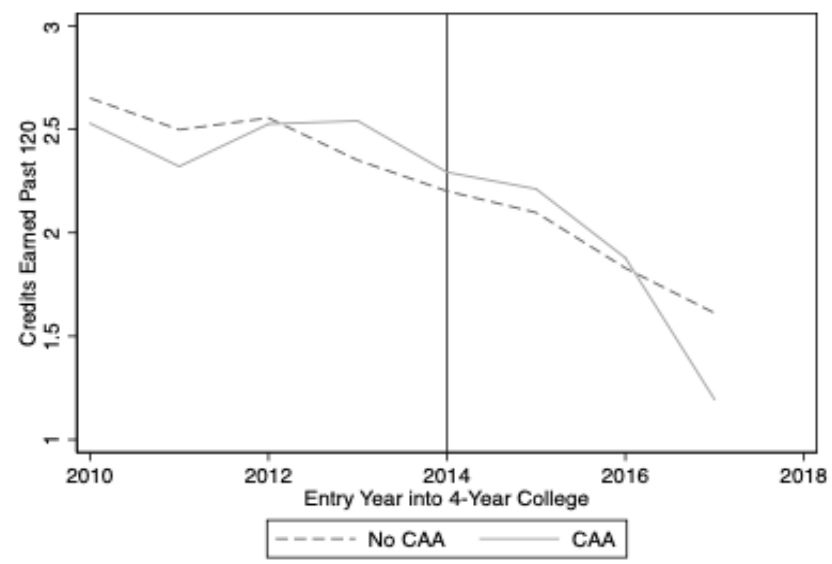

Note: Students in this plot are Black

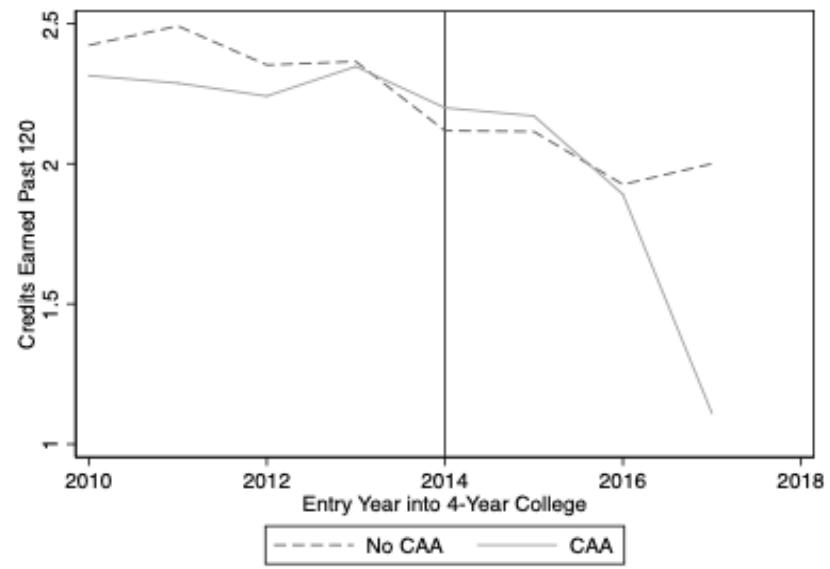

Note: Students in this plot are Latinx

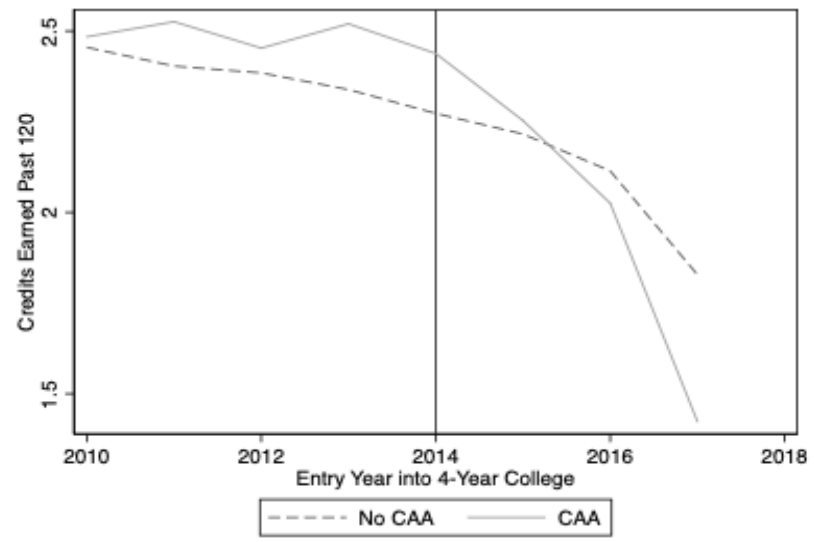

Note: Students in this plot are White 


\section{Results}

\section{Two-Year Completion}

Our first outcome, which examined the role of the CAA in enabling students to adhere to the $2+2$ timeline, as encouraged by the CAA policy, found null results. Black, Latinx, and White students were no more nor no less likely to graduate in two academic years post-transfer (6 consecutive semesters) regardless of whether policy implementation occurred in 2014 or 2016. See Tables 7-9 for results.

\section{Table 7}

Effects of CAA Policy on 2-Year Completion for Black Students

\begin{tabular}{|c|c|c|c|c|}
\hline & \multicolumn{2}{|c|}{ Model 1: Policy in 2014} & \multicolumn{2}{|c|}{ Model 2: Policy in 2016} \\
\hline & Empty DID & Full Model & Empty DID & Full Model \\
\hline \multirow[t]{2}{*}{ CAA X Post Interaction } & -0.02 & -0.03 & -0.08 & 0.01 \\
\hline & $(0.05)$ & $(0.04)$ & $(0.07)$ & $(0.06)$ \\
\hline \multirow[t]{2}{*}{ Enrolled in CAA Qualifying Degree } & $0.15^{* *}$ & $0.09 * *$ & $0.15^{* *}$ & $0.07 * *$ \\
\hline & $(0.04)$ & $(0.03)$ & $(0.04)$ & $(0.02)$ \\
\hline \multirow[t]{2}{*}{ Post Policy Implementation } & 0.06 & $0.09 * *$ & $0.18^{* * *}$ & $0.09 *$ \\
\hline & $(0.03)$ & $(0.02)$ & $(0.05)$ & $(0.03)$ \\
\hline \multirow[t]{2}{*}{ From Rural County } & & -0.02 & & -0.02 \\
\hline & & $(0.03)$ & & $(0.03)$ \\
\hline \multirow[t]{2}{*}{ Received Pell Grant } & & $-0.09 * * *$ & & $-0.09 * *$ \\
\hline & & $(0.03)$ & & $(0.03)$ \\
\hline \multirow[t]{2}{*}{ Female } & & 0.02 & & 0.02 \\
\hline & & $(0.02)$ & & $(0.02)$ \\
\hline \multirow[t]{2}{*}{ STEM Major } & & $-0.09 * * *$ & & $-0.09 * * *$ \\
\hline & & $(0.02)$ & & $(0.02)$ \\
\hline \multirow[t]{2}{*}{$\mathrm{AP} / \mathrm{IB}$} & & $0.28^{*}$ & & $0.27 *$ \\
\hline & & $(0.11)$ & & $(0.10)$ \\
\hline \multirow[t]{2}{*}{ Enrolled Part Time } & & $-0.17 * * *$ & & $-0.16^{* * *}$ \\
\hline & & $(0.01)$ & & $(0.02)$ \\
\hline \multirow[t]{2}{*}{ Major Changes } & & $-0.07 * * *$ & & $-0.07 * * *$ \\
\hline & & $(0.01)$ & & $(0.01)$ \\
\hline \multirow[t]{2}{*}{ Hours Transferred to 4-Year } & & $0.01 * * *$ & & $0.01 * * *$ \\
\hline & & $(0.00)$ & & $(0.00)$ \\
\hline \multirow[t]{2}{*}{ Constant } & $0.17 * * *$ & $0.14^{*}$ & $0.18^{* * *}$ & $0.16^{* *}$ \\
\hline & $(0.03)$ & $(0.05)$ & $(0.03)$ & $(0.05)$ \\
\hline$N$ & 4,373 & 4,373 & 4,373 & 4,373 \\
\hline
\end{tabular}

Note: $* p<0.05 * * p<0.01 * * * p<0.001$. Standard errors clustered at four-year institution. 


\section{Table 8}

Effects of CAA Policy on 2-Year Completion for Latinx Students

\begin{tabular}{|c|c|c|c|c|}
\hline & \multicolumn{2}{|c|}{ Model 3: Policy in 2014} & \multicolumn{2}{|c|}{ Model 4: Policy in 2016} \\
\hline & Empty DID & Full Model & Empty DID & Full Model \\
\hline \multirow[t]{2}{*}{ CAA X Post Interaction } & -0.00 & 0.01 & -0.03 & -0.02 \\
\hline & $(0.02)$ & $(0.02)$ & $(0.06)$ & $(0.05)$ \\
\hline \multirow[t]{2}{*}{ Enrolled in CAA Qualifying Degree } & $0.20^{* * *}$ & $0.13^{* * *}$ & $0.19^{* * *}$ & $0.14^{* * *}$ \\
\hline & $(0.03)$ & $(0.03)$ & $(0.03)$ & $(0.03)$ \\
\hline \multirow[t]{2}{*}{ Post Policy Implementation } & 0.03 & $0.07 * *$ & $0.11 * * *$ & $0.10^{* *}$ \\
\hline & $(0.02)$ & $(0.02)$ & $(0.03)$ & $(0.03)$ \\
\hline \multirow[t]{2}{*}{ From Rural County } & & -0.02 & & -0.02 \\
\hline & & $(0.03)$ & & $(0.03)$ \\
\hline \multirow[t]{2}{*}{ Received Pell Grant } & & $-0.11 * * *$ & & $-0.10^{* * *}$ \\
\hline & & $(0.02)$ & & $(0.02)$ \\
\hline \multirow[t]{2}{*}{ Female } & & $0.03^{*}$ & & $0.03 *$ \\
\hline & & $(0.01)$ & & $(0.01)$ \\
\hline \multirow[t]{2}{*}{ STEM Major } & & $-0.11 * * *$ & & $-0.11 * * *$ \\
\hline & & $(0.03)$ & & $(0.02)$ \\
\hline \multirow[t]{2}{*}{$\mathrm{AP} / \mathrm{IB}$} & & $0.13^{* * *}$ & & $0.12^{* *}$ \\
\hline & & $(0.03)$ & & $(0.03)$ \\
\hline \multirow[t]{2}{*}{ Enrolled Part Time } & & $-0.20 * * *$ & & $-0.19 * * *$ \\
\hline & & $(0.03)$ & & $(0.03)$ \\
\hline \multirow[t]{2}{*}{ Major Changes } & & $-0.07 * * *$ & & $-0.07 * * *$ \\
\hline & & $(0.01)$ & & $(0.01)$ \\
\hline \multirow[t]{2}{*}{ Hours Transferred to 4-Year } & & $0.00 * * *$ & & $0.00 * * *$ \\
\hline & & $(0.00)$ & & $(0.00)$ \\
\hline \multirow[t]{2}{*}{ Constant } & $0.17 * * *$ & $0.22 * * *$ & $0.17 * * *$ & $0.22 * * *$ \\
\hline & $(0.04)$ & $(0.05)$ & $(0.04)$ & $(0.05)$ \\
\hline$N$ & 2,183 & 2,183 & 2,183 & 2,183 \\
\hline
\end{tabular}

Note: $* p<0.05 * * p<0.01 * * * p<0.001$. Standard errors clustered at four-year institution. 


\section{Table 9}

Effects of CAA Policy on 2-Year Completion for White Students

\begin{tabular}{|c|c|c|c|c|}
\hline & \multicolumn{2}{|c|}{ Model 5: Policy in 2014} & \multicolumn{2}{|c|}{ Model 6: Policy in 2016} \\
\hline & Empty DID & Full Model & Empty DID & Full Model \\
\hline \multirow[t]{2}{*}{ CAA X Post Interaction } & 0.01 & 0.03 & -0.01 & 0.04 \\
\hline & $(0.03)$ & $(0.02)$ & $(0.03)$ & $(0.02)$ \\
\hline \multirow[t]{2}{*}{ Enrolled in CAA Qualifying Degree } & $0.13^{* * *}$ & $0.07 * *$ & $0.14^{* * *}$ & $0.08^{* * *}$ \\
\hline & $(0.03)$ & $(0.02)$ & $(0.03)$ & $(0.02)$ \\
\hline \multirow[t]{2}{*}{ Post Policy Implementation } & $0.06^{*}$ & $0.08^{* * *}$ & $0.13^{* * *}$ & $0.09 * *$ \\
\hline & $(0.03)$ & $(0.02)$ & $(0.04)$ & $(0.02)$ \\
\hline \multirow[t]{2}{*}{ From Rural County } & & 0.02 & & 0.02 \\
\hline & & $(0.01)$ & & $(0.01)$ \\
\hline \multirow[t]{2}{*}{ Received Pell Grant } & & $-0.08 * * *$ & & $-0.08 * * *$ \\
\hline & & $(0.01)$ & & $(0.01)$ \\
\hline \multirow[t]{2}{*}{ Female } & & 0.02 & & 0.02 \\
\hline & & $(0.01)$ & & $(0.01)$ \\
\hline \multirow[t]{2}{*}{ STEM Major } & & $-0.15^{* * *}$ & & $-0.14 * * *$ \\
\hline & & $(0.02)$ & & $(0.02)$ \\
\hline \multirow[t]{2}{*}{$\mathrm{AP} / \mathrm{IB}$} & & $0.11 *$ & & $0.11 *$ \\
\hline & & $(0.05)$ & & $(0.04)$ \\
\hline \multirow[t]{2}{*}{ Enrolled Part Time } & & $-0.19 * * *$ & & $-0.17 * * *$ \\
\hline & & $(0.02)$ & & $(0.01)$ \\
\hline \multirow[t]{2}{*}{ Major Changes } & & $-0.09 * * *$ & & $-0.09 * * *$ \\
\hline & & $(0.01)$ & & $(0.01)$ \\
\hline \multirow[t]{2}{*}{ Hours Transferred to 4-Year } & & $0.01 * * *$ & & $0.01 * * *$ \\
\hline & & 0 & & $(0.00)$ \\
\hline \multirow[t]{2}{*}{ Constant } & $0.25^{* * *}$ & $0.15^{*}$ & $0.26^{* * *}$ & $0.16^{* *}$ \\
\hline & $(0.03)$ & $(0.06)$ & $(0.03)$ & $(0.05)$ \\
\hline$N$ & 22,359 & 22,359 & 22,359 & 22,359 \\
\hline
\end{tabular}

Note: $* p<0.05 * * p<0.01 * * * p<0.001$. Standard errors clustered at four-year institution.

\section{Time to Degree}

The next set of analyses explored the impact of the CAA on time to degree, which revealed that the policy increased how long baccalaureate degree completers took to finish their degrees. As shown in Table 10, CAA-qualifying Black students who transferred in or after Fall 2014 spent, on average, three quarters of a semester longer at the four-year university than those who transferred with non-CAA-qualifying degrees or no degree at all $(\beta=0.79, p<0.05)$. The effect of the CAA decreased over time, though, as students who entered in Fall 2016 or later spent around half of a semester longer at the four-year university $(\beta=0.52, p<0.05)$. 


\section{Table 10}

Effects of CAA Policy on Time to Degree for Black Students

\begin{tabular}{|c|c|c|c|c|}
\hline & \multicolumn{2}{|c|}{ Model 7: Policy in 2014} & \multicolumn{2}{|c|}{ Model 8: Policy in 2016} \\
\hline & Empty DID & Full Model & Empty DID & Full Model \\
\hline \multirow[t]{2}{*}{ CAA X Post Interaction } & $0.68^{*}$ & $0.79 *$ & $1.45^{* * *}$ & $0.52 *$ \\
\hline & $(0.28)$ & $(0.28)$ & $(0.30)$ & $(0.20)$ \\
\hline \multirow[t]{2}{*}{ Enrolled in CAA Qualifying Degree } & $-1.64 * * *$ & $-1.07 * * *$ & $-1.47^{* * *}$ & $-0.74 * * *$ \\
\hline & $(0.29)$ & $(0.21)$ & $(0.23)$ & $(0.15)$ \\
\hline \multirow[t]{2}{*}{ Post Policy Implementation } & $-1.73^{* * *}$ & $-2.08^{* * *}$ & $-3.20 * * *$ & $-2.36 * * *$ \\
\hline & $(0.17)$ & $(0.17)$ & $(0.23)$ & $(0.19)$ \\
\hline \multirow[t]{2}{*}{ From Rural County } & & 0.09 & & -0.08 \\
\hline & & $(0.17)$ & & $(0.16)$ \\
\hline \multirow[t]{2}{*}{ Received Pell Grant } & & $0.52 *$ & & $0.48^{*}$ \\
\hline & & $(0.18)$ & & $(0.20)$ \\
\hline \multirow[t]{2}{*}{ Female } & & -0.18 & & -0.16 \\
\hline & & $(0.10)$ & & $(0.11)$ \\
\hline \multirow[t]{2}{*}{ STEM Major } & & $0.78^{* * *}$ & & $0.73^{* *}$ \\
\hline & & $(0.17)$ & & $(0.19)$ \\
\hline \multirow[t]{2}{*}{$\mathrm{AP} / \mathrm{IB}$} & & $-2.02^{*}$ & & $-1.87 *$ \\
\hline & & $(0.78)$ & & $(0.68)$ \\
\hline \multirow[t]{2}{*}{ Enrolled Part Time } & & $2.01 * * *$ & & $1.70^{* * *}$ \\
\hline & & $(0.10)$ & & $(0.10)$ \\
\hline \multirow[t]{2}{*}{ Major Changes } & & $0.93^{* * *}$ & & $0.90^{* * *}$ \\
\hline & & $(0.12)$ & & $(0.13)$ \\
\hline \multirow[t]{2}{*}{ Hours Transferred to 4-Year } & & $-0.05^{* * *}$ & & $-0.04 * * *$ \\
\hline & & $(0.01)$ & & $(0.01)$ \\
\hline \multirow[t]{2}{*}{ Constant } & $9.72 * * *$ & $9.60^{* * *}$ & $9.35^{* * *}$ & $9.17 * * *$ \\
\hline & $(0.21)$ & $(0.46)$ & $(0.21)$ & $(0.48)$ \\
\hline$N$ & 4,520 & 4,520 & 4,520 & 4,520 \\
\hline
\end{tabular}

Note: $* p<0.05 * * p<0.01 * * * p<0.001$. Standard errors clustered at four-year institution.

Initially, the effect of the policy was weaker for Latinx students than it was for Black students; however, unlike among Black students, the effect of the CAA among Latinx students increased over time. Our model with policy implementation in 2014 showed that Latinx students spent no more nor no less time enrolled at the four-year university post-CAA $(\beta=0.38, p>0.05)$. Again, our models suggested that the effect of the policy increased over time, as Latinx students who entered the four-year university in or after Fall 2016 spent three quarters of a semester longer there $(\beta=0.74, p<0.001)$. See Table 11 for results. 
Table 11

Effects of $C A A$ Policy on Time to Degree for Latinx Students

\begin{tabular}{|c|c|c|c|c|}
\hline & \multicolumn{2}{|c|}{ Model 9: Policy in 2014} & \multicolumn{2}{|c|}{ Model 10: Policy in 2016} \\
\hline & Empty DID & Full Model & Empty DID & Full Model \\
\hline \multirow[t]{2}{*}{ CAA X Post Interaction } & $0.54 *$ & 0.38 & $0.87 * * *$ & $0.74 * * *$ \\
\hline & $(0.20)$ & $(0.23)$ & $(0.13)$ & $(0.18)$ \\
\hline \multirow[t]{2}{*}{ Enrolled in CAA Qualifying Degree } & $-1.64 * * *$ & $-1.06^{* * *}$ & $-1.46^{* * *}$ & $-0.97 * * *$ \\
\hline & $(0.16)$ & $(0.15)$ & $(0.11)$ & $(0.13)$ \\
\hline \multirow[t]{2}{*}{ Post Policy Implementation } & $-1.46^{* * *}$ & $-1.56^{* * *}$ & $-2.32 * * *$ & $-2.12^{* * *}$ \\
\hline & $(0.20)$ & $(0.19)$ & $(0.21)$ & $(0.18)$ \\
\hline \multirow[t]{2}{*}{ From Rural County } & & 0.03 & & 0.01 \\
\hline & & $(0.23)$ & & $(0.24)$ \\
\hline \multirow[t]{2}{*}{ Received Pell Grant } & & $0.62 * * *$ & & $0.49 * *$ \\
\hline & & $(0.13)$ & & $(0.14)$ \\
\hline \multirow[t]{2}{*}{ Female } & & $-0.23^{* *}$ & & -0.25 \\
\hline & & $(0.10)$ & & $(0.13)$ \\
\hline \multirow[t]{2}{*}{ STEM Major } & & $0.76^{* * *}$ & & $0.76^{* * *}$ \\
\hline & & $(0.13)$ & & $(0.11)$ \\
\hline \multirow[t]{2}{*}{$\mathrm{AP} / \mathrm{IB}$} & & $-0.74 * * *$ & & $-0.70 * * *$ \\
\hline & & $(0.15)$ & & $(0.15)$ \\
\hline \multirow[t]{2}{*}{ Enrolled Part Time } & & $1.54^{* * *} *$ & & $1.43^{* * *}$ \\
\hline & & $(0.10)$ & & $(0.11)$ \\
\hline \multirow[t]{2}{*}{ Major Changes } & & $0.68^{* * *}$ & & $0.63^{* * *}$ \\
\hline & & $(0.10)$ & & $(0.11)$ \\
\hline \multirow[t]{2}{*}{ Hours Transferred to 4-Year } & & $-0.03 * * *$ & & $-0.04 * * *$ \\
\hline & & $(0.01)$ & & $(0.01)$ \\
\hline \multirow[t]{2}{*}{ Constant } & $9.27 * * *$ & $8.93^{* * *}$ & $8.90^{* * *}$ & $8.79 * * *$ \\
\hline & $(0.30)$ & $(0.50)$ & $(0.24)$ & $(0.46)$ \\
\hline$N$ & 2,295 & 2,295 & 2,295 & 2,295 \\
\hline \multicolumn{5}{|c|}{ Note: $* p<0.05 * * p<0.01 * * * p<0.001$. Standard errors clustered at four-year institution. } \\
\hline \multicolumn{5}{|c|}{$\begin{array}{l}\text { Finally, we observed that the effect of the policy on White students was weaker than for } \\
\text { Black and Latinx students. White students who transferred in or after Fall } 2014 \text { spent one quarter of } \\
\text { a semester longer at the four-year university than they would have had the policy not been } \\
\text { implemented }(\beta=0.25, p<0.01) \text {. Like we observed among Latinx students, the effect of the CAA } \\
\text { increased over time, as those who entered in or after Fall } 2016 \text { spent around one third of a semester } \\
\text { longer at the four-year university }(\beta=0.34, p<0.001) \text {. See Table } 12 \text { for results. }\end{array}$} \\
\hline
\end{tabular}




\section{Table 12}

Effects of CAA Policy on Time to Degree for White Students

\begin{tabular}{|c|c|c|c|c|}
\hline & \multicolumn{2}{|c|}{ Model 11: Policy in 2014} & \multicolumn{2}{|c|}{ Model 12: Policy in 2016} \\
\hline & Empty DID & Full Model & Empty DID & Full Model \\
\hline \multirow[t]{2}{*}{ CAA X Post Interaction } & $0.36 *$ & $0.25^{* *}$ & $0.77 * * *$ & $0.34 * * *$ \\
\hline & $(0.16)$ & $(0.07)$ & $(0.13)$ & $(0.10)$ \\
\hline \multirow[t]{2}{*}{ Enrolled in CAA Qualifying Degree } & $-1.06 * * *$ & $-0.72 * * *$ & $-0.96 * * *$ & $-0.62 * * *$ \\
\hline & $(0.19)$ & $(0.10)$ & $(0.15)$ & $(0.08)$ \\
\hline \multirow[t]{2}{*}{ Post Policy Implementation } & $-1.29 * * *$ & $-1.47 * * *$ & $-2.17 * * *$ & $-1.81 * * *$ \\
\hline & $(0.17)$ & $(0.09)$ & $(0.16)$ & $(0.10)$ \\
\hline \multirow[t]{2}{*}{ From Rural County } & & $-0.12^{*}$ & & -0.12 \\
\hline & & $(0.05)$ & & $(0.06)$ \\
\hline \multirow[t]{2}{*}{ Received Pell Grant } & & $0.58^{* * *}$ & & $0.57 * * *$ \\
\hline & & $(0.06)$ & & $(0.06)$ \\
\hline \multirow[t]{2}{*}{ Female } & & $-0.15^{*}$ & & $-0.16^{*}$ \\
\hline & & $(0.07)$ & & $(0.07)$ \\
\hline \multirow[t]{2}{*}{ STEM Major } & & $0.83^{* * *}$ & & $0.80^{* * *}$ \\
\hline & & $(0.14)$ & & $(0.14)$ \\
\hline \multirow[t]{2}{*}{$\mathrm{AP} / \mathrm{IB}$} & & $-0.84^{*}$ & & $-0.79 * *$ \\
\hline & & $(0.29)$ & & $(0.25)$ \\
\hline \multirow[t]{2}{*}{ Enrolled Part Time } & & $1.63^{* * *}$ & & $1.39 * * *$ \\
\hline & & $(0.06)$ & & $(0.06)$ \\
\hline \multirow[t]{2}{*}{ Major Changes } & & $0.83^{* * *}$ & & $0.81 * * *$ \\
\hline & & $(0.06)$ & & $(0.07)$ \\
\hline \multirow[t]{2}{*}{ Hours Transferred to 4-Year } & & $-0.04 * * *$ & & $-0.04 * * *$ \\
\hline & & $(0.01)$ & & $(0.00)$ \\
\hline \multirow[t]{2}{*}{ Constant } & $8.59 * * *$ & $8.49 * * *$ & $8.30 * * *$ & $8.26^{* * *}$ \\
\hline & $(0.24)$ & $(0.39)$ & $(0.20)$ & $(0.36)$ \\
\hline$N$ & 23,230 & 23,230 & 23,230 & 23,230 \\
\hline
\end{tabular}

Note: $* p<0.05 * * p<0.01 * * * p<0.001$. Standard errors clustered at four-year institution.

\section{Excess Credits}

Our final analyses explored the impact of the 2014 CAA revision on excess credits past the baccalaureate degree's minimum requirement (120). Our models for Black students (shown in Table 13) found that initial policy implementation in 2014 increased the amount of credits students took past 120 . While marginally significant ${ }^{2}$, we found that Black students who transferred to a four-year

${ }^{2}$ We have included these findings in the results because the $p$-value for the estimate falls between the generally accepted, yet stringent, $p$-value of 0.05 and the less conservative $p$-value of 0.10 . While marginally significant, we believe the practical significance of this finding contributes to our understanding of the effects of the policy and should therefore be reported (Hubbard \& Lindsay, 2008) 
university with an AA or an AS degree during or after Fall 2014 earned 11\% more credits past 120 than they would have earned had the policy not been put into place $(\beta=0.11, p=0.10)$. The effect of the policy decreased over time, as we also found that Black students earned no more nor no fewer credits in the post-treatment time period in the models with policy implementation at 2016 ( $\beta$ $=-0.04, p>0.05)$.

\section{Table 13}

Effects of CAA Policy on the Log of Excess Credits Past 120 at 4-Year University Graduation for Black Students

\begin{tabular}{|c|c|c|c|c|}
\hline & \multicolumn{2}{|c|}{ Model 13: Policy in 2014} & \multicolumn{2}{|c|}{ Model 14: Policy in 2016} \\
\hline & Empty DID & Full Model & Empty DID & Full Model \\
\hline \multirow[t]{2}{*}{ CAA X Post Interaction } & 0.04 & 0.11 & -0.08 & -0.04 \\
\hline & $(0.06)$ & $(0.06)$ & $(0.09)$ & $(0.09)$ \\
\hline \multirow{2}{*}{$\begin{array}{l}\text { Enrolled in CAA Qualifying } \\
\text { Degree }\end{array}$} & -0.04 & 0.02 & 0.01 & 0.10 \\
\hline & $(0.12)$ & $(0.07)$ & $(0.12)$ & $(0.07)$ \\
\hline \multirow[t]{2}{*}{ Post Policy Implementation } & $-0.46 * * *$ & $-0.53 * * *$ & $-0.61 * *$ & $-0.62 * * *$ \\
\hline & $(0.07)$ & $(0.09)$ & $(0.15)$ & $(0.15)$ \\
\hline \multirow[t]{2}{*}{ From Rural County } & & 0.07 & & 0.02 \\
\hline & & $(0.06)$ & & $(0.05)$ \\
\hline \multirow[t]{2}{*}{ Received Pell Grant } & & 0.02 & & 0.00 \\
\hline & & $(0.10)$ & & $(0.09)$ \\
\hline \multirow[t]{2}{*}{ Female } & & 0.07 & & 0.08 \\
\hline & & $(0.06)$ & & $(0.05)$ \\
\hline \multirow[t]{2}{*}{ STEM Major } & & $0.78^{* *}$ & & $0.77 * *$ \\
\hline & & $(0.20)$ & & $(0.20)$ \\
\hline \multirow[t]{2}{*}{$\mathrm{AP} / \mathrm{IB}$} & & -0.10 & & 0.02 \\
\hline & & $(0.21)$ & & $(0.22)$ \\
\hline \multirow[t]{2}{*}{ Enrolled Part Time } & & $0.20 * *$ & & 0.12 \\
\hline & & $(0.06)$ & & $(0.06)$ \\
\hline \multirow[t]{2}{*}{ Major Changes } & & $0.14^{* *}$ & & $0.13^{*}$ \\
\hline & & $(0.05)$ & & $(0.05)$ \\
\hline \multirow[t]{2}{*}{ Constant } & $2.52^{* * *}$ & $2.04 * * *$ & $2.39 * * *$ & $1.96^{* * *}$ \\
\hline & $(0.15)$ & $(0.08)$ & $(0.15)$ & $(0.09)$ \\
\hline$N$ & 4,530 & 4,530 & 4,530 & 4,530 \\
\hline
\end{tabular}

Note: $* p<0.05 * * p<0.01 * * * p<0.001$. Standard errors clustered at four-year institution. We did not include hours transferred to the four-year university in this analysis because these hours are included in the outcome variable.

Excess credit-earning among Latinx students appears to be unaffected by the policy change. Table 14 shows that these students earned no more nor no fewer credits past 120 after policy implementation, no matter whether the implementation is considered to have occurred in 2014 ( $\beta=$ $0.06, p>0.05)$ or in $2016(\beta=-0.25, p>0.05)$. 


\section{Table 14}

Effects of CAA Policy on the Log of Excess Credits Past 120 at 4-Year University Graduation for Latinx Students

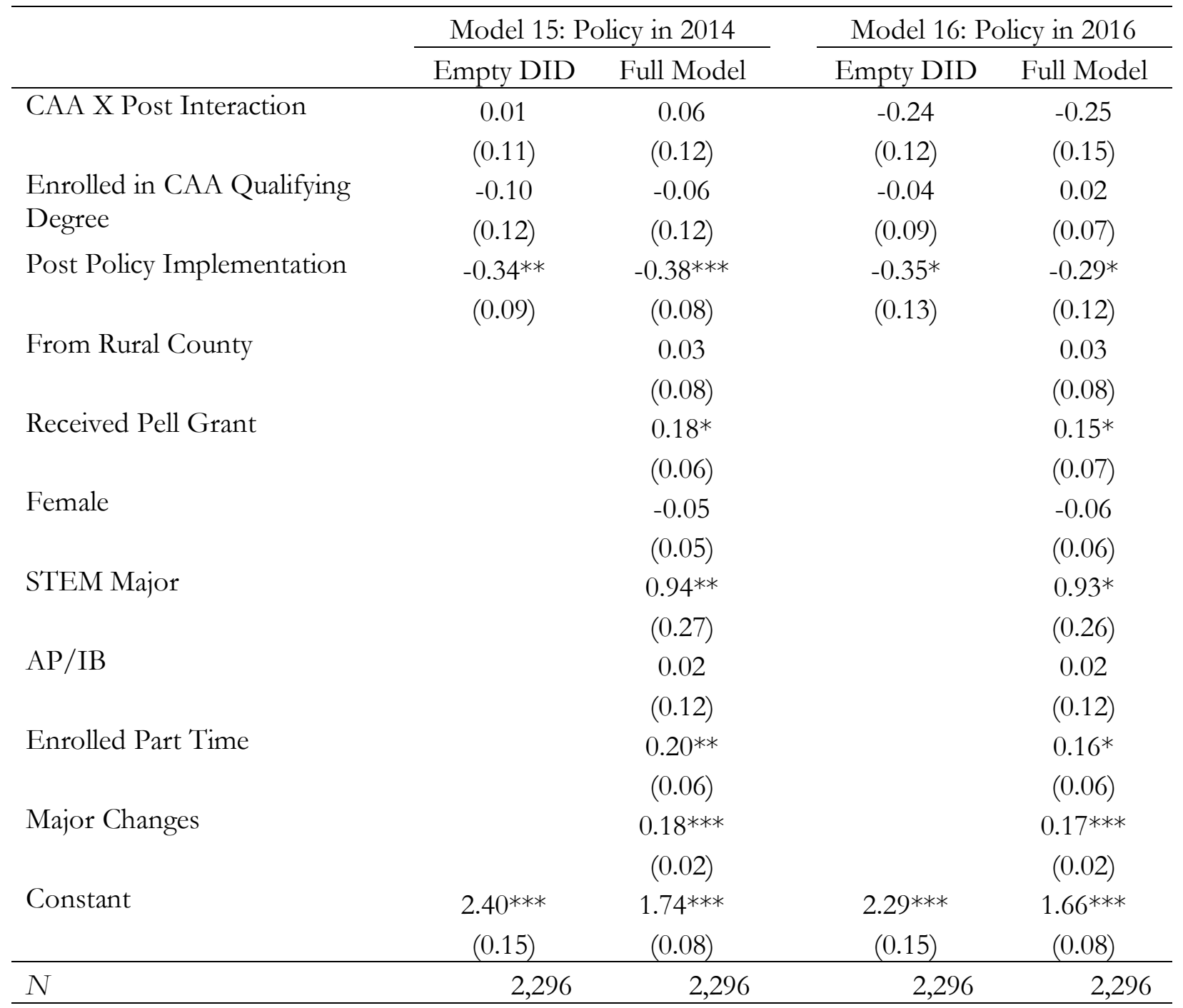

Note: $* p<0.05 * * p<0.01 * * * p<0.001$. Standard errors clustered at four-year institution. We did not include hours transferred to the four-year university in this analysis because these hours are included in the outcome variable.

The same models for White students (shown in Table 15) indicated that the policy had no effect on the amount of additional credits they earned upon graduation with policy implementation in 2014 ( $\beta=-0.12, p>0.05)$. However, it appears that the policy may have had a delayed treatment effect for White students, as these students earned $27 \%$ fewer credits past 120 upon graduation when the policy is considered to have gone into effect in $2016(\beta=-0.27, p<0.01)$. 


\section{Table 15}

Effects of CAA Policy on the Log of Excess Credits Past 120 at 4-Year University Graduation for White Students

\begin{tabular}{|c|c|c|c|c|}
\hline & \multicolumn{2}{|c|}{ Model 17: Policy in 2014} & \multicolumn{2}{|c|}{ Model 18: Policy in 2016} \\
\hline & Empty DID & Full Model & Empty DID & Full Model \\
\hline \multicolumn{5}{|l|}{ CAA X Post Interaction } \\
\hline & $-0.14^{*}$ & -0.12 & $-0.28 * *$ & $-0.27 * *$ \\
\hline & $(0.06)$ & $(0.06)$ & $(0.08)$ & $(0.08)$ \\
\hline \multirow{2}{*}{$\begin{array}{l}\text { Enrolled in CAA Qualifying } \\
\text { Degree }\end{array}$} & 0.10 & 0.10 & 0.10 & 0.10 \\
\hline & $(0.08)$ & $(0.06)$ & $(0.08)$ & $(0.05)$ \\
\hline \multirow[t]{2}{*}{ Post Policy Implementation } & $-0.21 *$ & $-0.25^{* *}$ & $-0.30^{*}$ & $-0.25^{*}$ \\
\hline & $(0.08)$ & $(0.06)$ & $(0.12)$ & $(0.09)$ \\
\hline \multirow[t]{2}{*}{ From Rural County } & & -0.01 & & -0.01 \\
\hline & & $(0.02)$ & & $(0.03)$ \\
\hline \multirow[t]{2}{*}{ Received Pell Grant } & & $0.11 * *$ & & $0.10^{* *}$ \\
\hline & & $(0.03)$ & & $(0.03)$ \\
\hline \multirow[t]{2}{*}{ Female } & & $0.13^{* *}$ & & $0.12^{* *}$ \\
\hline & & $(0.04)$ & & $(0.04)$ \\
\hline \multirow[t]{2}{*}{ STEM Major } & & $0.70 * *$ & & $0.69 * *$ \\
\hline & & $(0.20)$ & & $(0.20)$ \\
\hline \multirow[t]{2}{*}{$\mathrm{AP} / \mathrm{IB}$} & & -0.01 & & 0.00 \\
\hline & & $(0.18)$ & & $(0.17)$ \\
\hline \multirow[t]{2}{*}{ Enrolled Part Time } & & $0.14 * *$ & & $-0.09 *$ \\
\hline & & $(0.04)$ & & $(0.04)$ \\
\hline \multirow[t]{2}{*}{ Major Changes } & & $0.21 * * *$ & & $0.21 * * *$ \\
\hline & & $(0.01)$ & & $(0.02)$ \\
\hline \multirow[t]{2}{*}{ Constant } & $2.40^{* * *}$ & $1.80^{* * *}$ & $2.34^{* * *}$ & $1.76^{* * *}$ \\
\hline & $(0.15)$ & $(0.04)$ & $(0.15)$ & $(0.04)$ \\
\hline$N$ & 23,254 & 23,254 & 23,254 & 23,254 \\
\hline
\end{tabular}

Note: $* p<0.05 * * p<0.01 * * * p<0.001$. Standard errors clustered at four-year institution. We did not include hours transferred to the four-year university in this analysis because these hours are included in the outcome variable.

\section{Robustness Checks}

For each of our analyses, we implemented a placebo test to explore the possibility that the results of our DID models were due to random chance or secular trends in our outcome variables over time and, importantly, not related to the CAA revisions at all. These tests took the regression form of our DID models, as summarized in equation (2), but used a fake implementation year prior to the CAA revisions (2011) and only included students who transferred before Fall 2014 (Furquim et al., 2020). If, in each of these placebo tests, the coefficient $\beta_{3}$ on the interaction terms CAA $\times$ Post was not statistically significant, but this same coefficient was significant in our primary 
analyses, then the results of these tests would support the claim that the CAA revisions significantly impacted student outcomes. Across the nine (9) regression models that we ran, summarized in Tables 16-18, there were no statistically significant outcomes. Therefore, we concluded that our primary regression models are reliable (Greene, 2012).

\section{Table 16}

Effects of Placebo CAA Policy on 2-Year Completion

\begin{tabular}{lccc}
\hline & White & Black & Latinx \\
\hline CAA X Post Interaction & 0.01 & -0.05 & 0.02 \\
Enrolled in CAA Qualifying Degree & $(0.03)$ & $(0.06)$ & $(0.09)$ \\
& $0.08^{* *}$ & $0.13^{*}$ & 0.14 \\
Post Policy Implementation & $(0.03)$ & $(0.06)$ & $(0.07)$ \\
& 0.02 & 0.04 & 0.00 \\
From Rural County & $(0.01)$ & $(0.02)$ & $(0.05)$ \\
& 0.02 & -0.00 & $-0.08^{*}$ \\
Received Pell Grant & $(0.01)$ & $(0.04)$ & $(0.03)$ \\
& $-0.10^{* * *}$ & $-0.11^{* *}$ & $-0.14^{* * *}$ \\
Female & $(0.01)$ & $(0.03)$ & $(0.02)$ \\
STEM Major & 0.01 & 0.03 & 0.03 \\
AP/IB & $(0.01)$ & $(0.01)$ & $(0.03)$ \\
& $0.16^{*}$ & $0.41^{* *}$ & $0.18^{* *}$ \\
Enrolled Part Time & $(0.06)$ & $(0.14)$ & $(0.06)$ \\
Major Changes & $-0.12^{* * *}$ & $-0.07^{*}$ & $-0.12^{* * *}$ \\
Hours Transferred to 4-Year & $(0.02)$ & $(0.02)$ & $(0.02)$ \\
Constant & $-0.25^{* * *}$ & $-0.21^{* * *}$ & $-0.24^{* * *}$ \\
& $(0.02)$ & $(0.03)$ & $(0.04)$ \\
& $-0.08^{* * *}$ & $-0.06^{* * *}$ & $-0.06^{* * *}$ \\
& $(0.01)$ & $(0.01)$ & $(0.01)$ \\
& $0.01^{* * *}$ & $0.00 * * *$ & $0.00^{*}$ \\
& $(0.00)$ & $(0.00)$ & $(0.00)$ \\
& $0.18^{* *}$ & $0.16^{* * *}$ & $0.33^{* *}$ \\
& $(0.06)$ & $(0.04)$ & $(0.08)$ \\
\hline
\end{tabular}

Note: $* p<0.05 * * p<0.01 * * * p<0.001$. Standard errors clustered at four-year institution. 
Table 17

Effects of Placebo CAA Policy on Time to Degree

\begin{tabular}{|c|c|c|c|}
\hline & White & Black & Latinx \\
\hline \multirow[t]{2}{*}{ CAA X Post Interaction } & 0.21 & 0.75 & 0.25 \\
\hline & $(0.15)$ & $(0.37)$ & $(0.49)$ \\
\hline \multirow[t]{2}{*}{ Enrolled in CAA Qualifying Degree } & $-0.84 * * *$ & $-1.56^{* *}$ & $-1.26^{*}$ \\
\hline & $(0.17)$ & $(0.49)$ & $(0.48)$ \\
\hline \multirow[t]{2}{*}{ Post Policy Implementation } & $-0.39 * *$ & $-0.84^{* *}$ & -0.19 \\
\hline & $(0.12)$ & $(0.27)$ & $(0.32)$ \\
\hline \multirow[t]{2}{*}{ From Rural County } & -0.06 & 0.05 & 0.40 \\
\hline & $(0.07)$ & $(0.28)$ & $(0.25)$ \\
\hline \multirow[t]{2}{*}{ Received Pell Grant } & $0.72^{* * *}$ & 0.62 & $0.87 * *$ \\
\hline & $(0.08)$ & $(0.30)$ & $(0.28)$ \\
\hline \multirow[t]{2}{*}{ Female } & -0.12 & -0.11 & -0.26 \\
\hline & $(0.10)$ & $(0.16)$ & $(0.21)$ \\
\hline \multirow[t]{2}{*}{ STEM Major } & $0.79 * * *$ & $0.81 * *$ & $0.90 * * *$ \\
\hline & $(0.19)$ & $(0.21)$ & $(0.15)$ \\
\hline \multirow[t]{2}{*}{$\mathrm{AP} / \mathrm{IB}$} & $-1.20^{* *}$ & $-3.02 * *$ & $-1.20 * * *$ \\
\hline & $(0.38)$ & $(0.94)$ & $(0.22)$ \\
\hline \multirow[t]{2}{*}{ Enrolled Part Time } & $2.35^{* * *}$ & $2.86^{* * *}$ & $2.37 * * *$ \\
\hline & $(0.09)$ & $(0.10)$ & $(0.14)$ \\
\hline \multirow[t]{2}{*}{ Major Changes } & $0.95^{* * *}$ & $1.09 * * *$ & $0.76^{* *}$ \\
\hline & $(0.10)$ & $(0.23)$ & $(0.20)$ \\
\hline \multirow[t]{2}{*}{ Hours Transferred to 4-Year } & $-0.04 * * *$ & $-0.05 * * *$ & $-0.04 *$ \\
\hline & $(0.01)$ & $(0.01)$ & $(0.01)$ \\
\hline \multirow[t]{2}{*}{ Constant } & $8.39 * * *$ & $9.73^{* * *}$ & $8.48^{* * *}$ \\
\hline & $(0.53)$ & $(0.59)$ & $(0.85)$ \\
\hline$N$ & 12,844 & 2,501 & 1,054 \\
\hline
\end{tabular}

Note: $* p<0.05 * * p<0.01 * * * p<0.001$. Standard errors clustered at four-year institution. 


\section{Table 18}

Effects of Placebo CAA Policy on the Log of Excess Credits Past 120 at 4-Year University Graduation

\begin{tabular}{lccc}
\hline & White & Black & Latinx \\
\hline CAA X Post Interaction & 0.06 & 0.05 & -0.06 \\
Enrolled in CAA Qualifying & $(0.06)$ & $(0.11)$ & $(0.14)$ \\
Degree & -0.06 & -0.02 & -0.09 \\
Post Policy Implementation & $(0.08)$ & $(0.10)$ & $(0.22)$ \\
& -0.07 & -0.14 & 0.10 \\
From Rural County & $(0.05)$ & $(0.07)$ & $(0.11)$ \\
& -0.00 & -0.02 & -0.03 \\
Received Pell Grant & $(0.02)$ & $(0.10)$ & $(0.13)$ \\
& $0.13^{* *}$ & 0.04 & 0.18 \\
Female & $(0.04)$ & $(0.08)$ & $(0.11)$ \\
STEM Major & $0.14 * *$ & 0.10 & 0.01 \\
AP/IB & $(0.04)$ & $(0.06)$ & $(0.10)$ \\
& $0.69 * *$ & $0.77 * *$ & $0.90 * *$ \\
Enrolled Part Time & $(0.22)$ & $(0.24)$ & $(0.22)$ \\
Major Changes & 0.09 & 0.14 & 0.02 \\
Constant & $(0.17)$ & $(0.16)$ & $(0.13)$ \\
& 0.10 & $0.20 * *$ & -0.01 \\
$N$ & $(0.05)$ & $(0.05)$ & $(0.06)$ \\
& $0.22^{* * *}$ & $0.14 *$ & $0.12^{*}$ \\
& $(0.02)$ & $(0.06)$ & $(0.05)$ \\
& $1.83^{* * *}$ & $2.13 * * *$ & $(0.13)$ \\
\hline
\end{tabular}

Note: $* p<0.05 * * p<0.01 * * * p<0.001$. Standard errors clustered at four-year institution. We did not include hours transferred to the four-year university in this analysis because these hours are included in the outcome variable.

\section{Limitations}

Although this study is innovative in its exploration of the impact of the CAA on the outcomes of students representing different racial/ethnic groups, it is not without its limitations. First, because our dataset derives from the University of North Carolina System (rather than the North Carolina Community College System), we were not able to explore the impact of the CAA on students' decisions to transfer or not. That is, our data included only students who did transfer to the four-year sector, and thus our results were unable to speak to the impact of the CAA on students who may not have transferred prior to its implementation but did so afterwards. Next, to explore the impact of the CAA on baccalaureate completion, we were limited to a two-year completion outcome due to the recency of the policy. With more time, we will be able to evaluate 
the impact of the policy change on longer-term completion outcomes, such as three- and four-year completion. A third limitation is that the dataset we used was lacking in some covariates that ideally would have been included in our statistical models, specifically covariates related to financial aid (e.g., student loan amounts) and campus involvement (e.g., participation in an honors program). Each of these categories of covariates has the potential to impact a student's educational trajectory. In addition, our time-to-degree analysis assumed a student was continuously enrolled. That is, if a student stopped out for a term and then re-enrolled, we did not observe this behavior in our dataset. As such, our time-to-degree analysis represented terms of potential rather than actual enrollment. Furthermore, while we utilized 120 as the cutoff for our excess credits analysis, we recognize that students in degree programs like nursing may have more courses in their program of study than students in other majors. We attempted to address this by controlling for students' majors in our analyses; however, future research should attempt to understand the effects of articulation agreements on students in specialized majors.

Finally, due to issues surrounding sample size and statistical power, we were unable to include analyses on Asian and Native American students. This is problematic, as researchers often group Asian students with White students, and Native American students with other students of Color for analytic purposes (Teranishi, 2007) — meaning these students are rarely studied in their own rights. While we recognize that omitting these students from our analyses does not solve this issue, we felt that combining these students into larger groups containing individuals from other racial/ethnic identities might mask or inaccurately describe the effects of the CAA on these students' transfer outcomes. Additionally, we recognize that the educational experiences of all students within larger categorizations of race/ethnicity are not the same, and researchers should be mindful of the difference between subpopulations. Unfortunately, our secondary dataset did not contain data that would allow us to disaggregate by factors like ethnic, social, or immigrant subgroup. We implore future quantitative researchers to consider including these factors when collecting data.

\section{Discussion}

This study evaluated the impact of the revised North Carolina Comprehensive Articulation Agreement (CAA), governing transfer from the North Carolina Community College System (NCCCS) to the University of North Carolina (UNC) System, on three key student outcomes: twoyear baccalaureate completion, time to degree, and accumulation of excess credits. Guided by a Critical Policy Analysis framework, we sought to identify potential consequences of the CAA (Allan et al., 2010) by identifying "policy 'winners' and 'losers"' and "the broader effect a given policy has on relationships of inequality and privilege” (Diem et al., 2014, p. 843), specifically regarding a student's racial/ethnic identity. Our focus on racial/ethnic identity derived from prior research, which found that these articulation policies often do not mention race explicitly (Chase et al., 2014). Through a disaggregation of our data, we were able to study each racial/ethnic group in its own right, thus acknowledging historic inequities in access to resources and opportunities among different groups of students (Teranishi, 2007). Studies such as this one are important in that they provide insight into how students from different backgrounds experience higher education in the United States, illuminating existing stratification and inequalities in access to the benefits of higher education, which are increasingly necessary for economic mobility and stability (Carnevale et al., 2011; Ma et al., 2019). Our results indicate that North Carolina's revised CAA promotes barriers to educational success, and associated economic mobility opportunities, among students identifying with certain racial/ethnic groups. Our results are, in fact, similar to those of Kosiewicz and Ngo (2020), who found that the option to self-place into mathematics courses (i.e., developmental or 
college-level) was associated with positive academic outcomes, such as completion of college-level mathematics, for White students but not for Black or Latinx students.

Specifically, our difference-in-differences analyses revealed several key findings. While we found no relationship between the CAA revisions and the likelihood that a student would complete a baccalaureate degree within two years of transfer for any of our three racial/ethnic groups, we did observe significant policy impacts for both time to degree and excess credit accumulation. As time passes since policy implementation, more semesters of data will become available, and we may then observe a significant relationship between the CAA implementation and baccalaureate degree completion. Our results suggested that the CAA revisions related to an increase in time to degree for all students, a finding in line with results from Boatman and Soliz (2018). However, our disaggregated results suggested that the impact of the policy was stronger for Black and Latinx students. That is, while the CAA was associated with an average increase in time to degree of around 0.2 to 0.3 of a semester for White students, the associated increase was around 0.7 to 0.8 for Black and Latinx students. Practically speaking, this means that, on average, the CAA appears to have induced more Black and Latinx students to take an additional semester to graduate compared to White students. We also found that the CAA revisions appeared to have a negative effect on excesscredit-earning behavior among White students, a positive result; however, the policy revisions were also related to an increase in excess credit earning among Black students ${ }^{3,4}$. Fink et al. (2018) found nationally that Black students experienced more excess credit accumulation, while Giani (2019) found that students of Color were more likely to experience credit loss. Giani further posits that underserved students may need additional support as they navigate the transfer process, and their higher likelihood of credit loss is a symptom of unmet need. Our results suggest that the CAA does not ameliorate this situation for Black students and perhaps perpetuates inequality, as they earn more excess credits after the policy revisions.

Our results, of course, raise the question as to why we observed these differential impacts of the CAA revisions by race/ethnicity, when policymakers intended the revisions to be beneficial for all students. While the CAA was not designed to benefit historically marginalized students, such as Black or Latinx students, specifically, these students certainly fall into the category of all students. Moreover, this policy has the potential to address some of the historical systemic inequities that we observe in the educational outcomes of these students (e.g., Hoachlander et al., 2003; Shapiro et al., 2018, Giani, 2019). Policies such as the CAA rely on the adequate relaying of information about policy provisions to students for effective implementation (Dynarski \& Scott-Clayton, 2006; Perna, 2006); that is, students are able to benefit from the policy only to the extent to which they are aware of its provisions and are provided with information about how to take advantage of them. For example, a student intending to complete a baccalaureate degree in biology would first need to be made aware that, under the policy, earning an AS degree is the most effective way of ensuring 60 transferable credits to the four-year institution. This student would also need to work with an advisor to find the appropriate baccalaureate degree plan for their program of choice at each potential institution of transfer or find the plan themselves on each four-year institution's website. (The complexity of this step is compounded by the fact that each UNC System institution might

\footnotetext{
${ }^{3}$ Subgroup analyses by gender, available upon request, indicated that this was especially true for Black women. ${ }^{4}$ We chose 120 credits as the cutoff point for this measure of excess credit accumulation since it is the standard minimum number of credits required for a baccalaureate degree; however, there are some degree programs that require more than 120 credits for students to complete their degrees. While we did control for major in our analyses, we also ran analyses with the cutoff point at 126 to ensure that our analyses were not affected by longer degree programs. We found that the estimates changed slightly using this different cutoff point; however, the direction of the coefficients remained the same.
} 
have slightly different requirements for the same degree program.) Finally, when it is time for this student to transfer, the student would need to be aware that admission to at least one UNC System institution is guaranteed as part of the CAA. However, just because admission is guaranteed to at least one institution, there is no guarantee that the student happened to be following the baccalaureate degree plan for the institution(s) to which they were accepted.

Reflecting CPA's focus on "[the] distribution of power, resources, and knowledge" (Diem et al., 2014, p. 843), differential access to information is one potential explanation for our findings. Importantly, we argue that the differential effects of the CAA by race/ethnicity are not due to certain characteristics of the student, rather their educational environments. One way in which students who intend to transfer and earn a baccalaureate degree learn about the CAA is through advising at their community college. Prior research has found that, among students in community college transfer programs, White students have historically received significantly more advising than do Black students (Herndon et al., 1996). Moreover, Orozco et al. (2010) found that advising use varies along racial lines among community college students, with Black and Latinx students experiencing greater barriers to accessing advising resources compared to White students. Moreover, few students of Color in Orozco and colleagues' study reported that an advisor had established a long-term relationship with them.

More recently, Maldonado (2019) found that counselors' perspectives of student potential are connected to beliefs that are both racialized and gendered. Low expectations and stereotypes that are communicated by advisors to students of Color can have a significant negative impact on their educational trajectories, including transfer (Kim \& Yeh, 2002). These students may experience similar situations inside the classroom. Harper et al. (2016) found that racist encounters with White professors in the classroom had a detrimental impact on Black students' academic performances. More generally, a projection of a deficit perspective onto students of Color may be a potential explanation for differences in how they perform academically. For example, North Carolina Community College System reports that Black students do not complete college-level mathematics and English courses at the same rates as do their White and Latinx counterparts (NCCCS, 2019). While community colleges have, in recent years, made significant strides towards improving advising, through the implementation of programs such as guided pathways (e.g., Jenkins \& Cho, 2014) and holistic advising (e.g., Hubbard, 2017), we currently do not know much about how these programs impact the outcomes of students of different racial/ethnic groups. Future work is needed to update the findings of Herndon et al. (1996) and Orozco et al. (2010) to explore the differential impact of these newer advising strategies on the outcomes of students of Color. Providing additional support for these newer advising models is one way to address the differential impact by race/ethnicity of the CAA that we observe in our study.

In addition to advising, another way in which students might access information about the CAA is through the Internet, where they are able to access baccalaureate degree plans published on UNC System institutions' websites. Recent estimates from the U.S. Census Bureau (2017) indicated that while approximately $21 \%$ of White households lack access to broadband Internet or a computer, approximately 36\% and 30\% of Black and Latinx households, respectively, do not have either of these resources. This differential access to web-based resources is an additional way in which Black and Latinx students are disadvantaged relative to their White peers in learning information about the CAA. Recent research in public policy suggests that this digital divide has important implications for communicating policy to various communities in general, and disadvantages historically marginalized communities in a number of ways (Brown et al., 2020). Increased attention to Internet access among NCCCS students is another potential way in which the differential impact of the CAA might be addressed. Students' use of the Internet to find information about transfer pathways is another useful direction for future research. 


\section{Implications for Policy and Practice and Conclusion}

Consistent with CPA, we offer suggestions for policymakers and practitioners aimed at ameliorating the racial inequality we observe in post-transfer outcomes. According to our findings, explicitly considering race/ethnicity when crafting policy is perhaps the most direct way to address the differential experiences of Black and Latinx students, on the one hand, and White students, on the other. Our results suggest that these student groups experience North Carolina's CAA differently; and, as a result, should be supported differently by educational policies and systems when it comes to promoting transfer success. For example, in future iterations of this legislation, policymakers could consider the inclusion of additional resources intended for specific student groups. Resources could be directed toward population-specific advising in both high school and community college so that students begin their community college career aware of the provisions available to them in the CAA. Armed with additional information, students may be better prepared to take advantage of the benefits that this policy provides.

Beyond their official websites, students increasingly interact with institutions of higher education through social media platforms, particularly as they progress closer to graduation (Sutherland et al., 2018). UNC System institutions could increase the visibility of baccalaureate degree plans (BDPs) through regular postings or advertisements of sample BDPs on Twitter, Instagram, and other social media platforms. Such posts could provide links to locations where all institutional BDPs could be found and to advisors that would be ready to chat or interact with potential students. To our knowledge, no public four-year institution in North Carolina has taken this step, but it has the potential to greatly enhance the transfer process for both students and universities.

In practice, our results suggest that high-quality advising and additional intervention for students from historically marginalized racial/ethnic groups cannot stop when a student arrives at a four-year institution. Indeed, the cost of an additional term of enrollment at the University of North Carolina at Chapel Hill (the state's flagship public four-year institution), an increase in time to degree experienced by both Black and Latinx transfer students after implementation of the CAA, is approximately $\$ 9,000$ (UNC Chapel Hill, 2020). This additional cost is a significant burden to all students, but especially to those from lower socioeconomic status backgrounds. It is important to keep in mind that all of the students in our dataset were successful at the community college; i.e., they all successfully transferred to a four-year institution and earned a baccalaureate degree. UNC System institutions must recognize their role in advancing the success of transfer students from all racial/ethnic groups, but they should pay specific attention to students from these historically marginalized groups. Additional resources could be allocated for providing students with appropriate advising and other interventions on campus, such as peer-mentoring programs or programs designed specifically for transfer students of Color. For example, Walker and Opkala (2017) found that Black transfer students expressed a need for additional resources that were tailored to their specific needs, including resources to address both academic and non-academic barriers that they face. In a recent study, McCall and Castles (2020) found that, according to staff members at a predominantly White institution, institutional services and support were lacking for Black transfer students. It is imperative that the work to advance the success of transfer students of Color does not stop once they transfer. It must be continued through graduation and subsequent employment.

In sum, our results indicated that, while North Carolina's CAA does not explicitly mention race (Chase et al., 2014), it does have differential impact on students' outcomes along racial/ethnic lines. That is, White students benefited more from this legislation than did Black or Latinx students (or were less harmed by it, in the case of time to degree) and, in the case of excess credits, Black 
students experienced worse outcomes after implementation. In focusing our research on differential outcomes of the CAA according to students' racial/ethnic identities, we highlight what Bensimon (2020) calls the "racist outcomes" (p. 7) of educational policy, referring to policy outcomes that benefit White students while not benefitting, and even harming, students from historically marginalized racial/ethnic groups. Bensimon (2020) suggests explicit mention of race and the inclusion of race-conscious solutions in policy as a positive step towards addressing educational systems that perpetuate inequality along racial and ethnic lines.

\section{References}

Alfonso, M. (2006). The impact of community college attendance on baccalaureate attainment. Research in Higher Education, 47(8), 873-903. https://doi.org/10.1007/s11162-006-9019-2

Allan, E. J., Iverson, S. D. V., \& Ropers-Huilman, R. (2010). Reconstructing policy in higher education: Feminist post-structural perspectives. Routledge.

American Psychological Association. (2017, July). Ethnic and racial minorities \& socioeconomic status. https://www.apa.org/pi/ses/resources/publications/minorities

Anderson, G., Sun, J. C., \& Alfonso, M. (2006). Effectiveness of statewide articulation agreements on the probability of transfer: A preliminary policy analysis. The Review of Higher Education, 29(3), 261-291. https://doi.org/10.1353/rhe.2006.0001

Angrist, J. D., \& Pischke, J. S. (2015). Mastering' metrics: The path from cause to effect. Princeton University Press.

Baker, R. (2016). The effects of structured transfer pathways in community colleges. Educational Evaluation and Policy Analysis, 38(4), 626-646. https:/doi.org10.3102/0162373716651491

Bensimon, E. M. (2020). The case for an anti-racist stance toward paying off higher education's racial debt. Change: The Magazine of Higher Learning, 52(2), 7-11. https://doi.org/10.1080/00091383.2020.1732752

Boatman, A., \& Soliz, A. (2018). Statewide transfer policies and community college student success. Education Finance and Policy, 13(4), 449-483. https://doi.org/0.1162/edfp_a_00233

Bridges, B. K., Kinzie, J., Nelson Laird, T. F., \& Kuh, G. D. (2008). Student engagement and student success at historically Black and Hispanic-serving institutions. In M. Gasman, B. Baez, \& C. S. V. Turner (Eds.), Understanding minority-serving institutions (pp. 217-236). SUNY Press.

Brown, A., Mossberger, K., \& Cho, S.K. (2020). Race, place, and digital governance. In A. Rutherford \& K.J. Meier (Eds.), Race and public administration (pp. 98-118). Taylor \& Francis.

Carnevale, A. P., Jayasundera, T., \& Gulish, A. (2016). America's divided recovery: College haves and havenots. Georgetown University's Center on Education and the Workforce. https://cew.georgetown.edu/cew-reports/americas-divided-recovery/\#full-report

Carnevale, A. P, Rose, S. J., \& Cheah, B. (2011, August). The college payoff: Education, occupations, lifetime earnings. Georgetown University's Center on Education and the Workforce. https://cew.georgetown.edu/cew-reports/the-college-payoff/\#full-report

Chang, M. J. (2003). Racial differences in viewpoints about contemporary issues among entering college students: Fact or fiction?. NASP A Journal, 40(4), 55-71. https://doi.org/10.2202/1949-6605.1280

Chase, M. M., Dowd, A. C., Pazich, L. B., \& Bensimon, E. (2014). Transfer equity for "minoritized" students: A critical policy analysis of seven states. Education Policy Studies, 28(5), 669-717. https://doi.org/10.1177/0895904812468227

Complete College America. (2020). Corequisite remediation: Spanning the completion divide. http://completecollege.org/spanningthedivide/\#the-bridge-builders

Cunningham, S. (2018). Causal inference: The mixtape. [Unpublished manuscript]. 
Diem, S., Young, M. D., Welton, A. D., Cummings Mansfield, K., \& Lee, P. (2014) The intellectual landscape of critical policy analysis. International Journal of Qualitative Studies in Education, 27(9), 1068-1090. https://doi.org/10.1080/09518398.2014.916007

Doyle, W. R. (2009). The effect of community college enrollment on bachelor's degree completion. Economics of Education Review, 28(2), 199-206. https://doi.org/10.1016/j.econedurev.2008.01.006

Dynarski, S., \& Scott-Clayton, J. (2006). The cost of complexity in federal student aid: Lessons from optimal tax theory and behavioral economics. National Tax Journal, 59(2), 319-356. https://doi.org/10.3386/w12227

Fink, J., Jenkins, D., Kopko, E., \& Ran, F. X. (2018). Using data mining to explore why community college transfer students earn bachelor's degrees with excess credit. [CCRC Working Paper No. 100]. Columbia University, Teachers College, Community College Research Center.

Furquim, F., Corral, D., \& Hillman, N. (2020). A primer for interpreting and designing difference-indifferences studies in higher education research. In L. W. Perna (Ed.), Higher education: Handbook of theory and research, 35 (pp. 1-58). Springer. https://doi.org/10.1007/978-3-03011743-6_5-1

Garcia, N. M., Lopez, N., \& Velez, V.N. (2018). QuantCrit: rectifying quantitative methods through critical race theory. Race Ethnicity and Education, 12(2), 149-157. https://doi.org/10.1080/13613324.2017.1377675

Giani, M. (2019). The correlates of credit loss: How demographics, pre-transfer academics, and institutions relate to the loss of credits for vertical transfer students. Research in Higher Education, 60(1), 1-29. https://doi.org/10.1007/s11162-019-09548-w

Gillborn, D., Warmington, P., \& Demack, S. (2018) QuantCrit: education, policy, 'Big Data', and principles for a critical race theory of statistics. Race Ethnicity and Education, 21(2), 158-179. https://doi.org/10.1080/13613324.2017.1377417

Goldrick-Rab, S. (2010). Challenges and opportunities for improving community college student success. Review of Educational Research, 80(3), 437-469. https://doi.org/10.3102/0034654310370163

González Canché, M. S. (2018). Nearby college enrollment and geographical skills mismatch: (Re)conceptualizing student out-migration in the American higher education system. The Journal of Higher Education, 89(6), 892-934. https:/ / doi.org/10.1080/00221546.2018.1442637

Harper, S. R., Smith, E. J., \& Davis, C. H. F. (2016). A critical race case analysis of black undergraduate student success at an urban university. Urban Education, 53(1), 3-25.

Harris, J. C., \& BrckaLorenz, A. (2017). Black, white, and biracial students' engagement at differing institutional types. Journal of College Student Development 58(5), 783-789. https://doi.org/10.1353/csd.2017.0061

Heck, R. H. (2004). Studying educational and social policy: Theoretical concepts and research methods. Lawrence Erlbaum Associates.

Herndon, J., Kaiser, J., \& Creamer, D. (1996). Student preferences for advising styles in community college environments. Journal of College Student Development, 37(6), 637-648 .

Higgins, C. S., \& Katsinas, S. G. (1999). The relationship between environmental conditions and transfer rates of selected rural community colleges: A pilot study. Community College Review, 27(2), 1-25. https://doi.org/10.1177/009155219902700201

Hillman, N. W. (2016). Geography of college opportunity: The case of education deserts. American Educational Research Journal, 53(4), 987-1021. https://doi.org/10.3102/0002831216653204

Hoachlander, G., Sikora, A. C., Horm, L., \& Carroll, C. D. (2003). Community college students: Goals, academic preparation, and outcomes. National Center for Education Statistics, U.S. Department of Education. 
Hodara, M., Martinez-Wenzl, M., Stevens, D., \& Mazzeo, C. (2017). Exploring credit mobility and major-specific pathways: A policy analysis and student perspective on community college to university transfer. Community College Review, 45(4), 331-349. https://doi.org/10.1177/0091552117724197

Hubbard, C. (2017). The role of holistic advising in the persistence of low-income adult students in community college: A case study [Doctoral dissertation]. George Mason University.

Hubbard, R., \& Lindsay, R. M. (2008). Why P values are not a useful measure of evidence in statistical significance testing. Theory \& Psychology, 18(1), 69-88. https://doi.org/10.1177/0959354307086923

Ignash, J. M., \& Townsend, B. K. (2000). Evaluating state-level articulation agreements according to good practice. Community College Review, 28(3). https://doi.org/10.1177/009155210002800301

Jackson, D. L. (2013). A balancing act: Impacting and initiating the success of African American female community college transfer students in STEM into the HBCU environment. The Journal of Negro Education, 82(3), 255-271. https://doi.org/10.7709/jnegroeducation.82.3.0255

Jenkins, D., \& Cho, S. W. (2013). Get with the program... and finish it: Building guided pathways to accelerate student completion. New Directions for Community Colleges, 2013(164), 27-35.

Kim, A., \& Yeh, C. J. (2002). Stereotypes of Asian American students. ERIC Digest, ERIC Clearinghouse on Urban Education. http://ericcass.uncg.edu/virtuallib/diversity/1077.html

King, G. (2019). A path toward completion? The impact of statewide articulation agreements on enrollment and attainment [Unpublished doctoral dissertation]. NC State University, Raleigh, NC.

Kosiewicz, H., \& Ngo, F. (2020). Giving community college students choice: The impact of selfplacement in math courses. American Educational Research Journal, 57(3), 1358-1391. https://doi.org/10.3102/0002831219872500

Kramer, D. A., Holcomb, M. R., \& Kelchen, R. (2018). The costs and consequences of excess credit hour policies. Educational Evaluation and Policy Analysis, 40(1), 3-28. https://doi.org/10.3102/0162373717709968

Long, B. T., \& Kurlaender, M. (2009). Do community colleges provide a viable pathway to a baccalaureate degree? Educational Evaluation and Policy Analysis, 31(1), 30-53. https://doi.org/10.3102/0162373708327756

Ma, J., Pender, M., \& Welch, M. (2019). Education pays 2019: The benefits of higher education for individuals and society. The College Board. https://research.collegeboard.org/pdf/education-pays-2019full-report.pdf

Maldonado, C. (2019). “Where your ethnic kids go:” How counselors as first responders legitimate proper course placements for community college students. Community College Journal of Research and Practice, 43(4), 280-294.

MGT of America. (2004, August 16). A study of the comprehensive articulation agreement between the University of North Carolina and the North Carolina Community College System. The North Carolina General Assembly.

https://www.ncleg.net/documentsites/committees/JLEOC/Reports\%20Received/Archive s/2004\%20Reports\%20Received/MGT\%20Study\%20of\%20the $\% 20$ Comprehensive $\% 20$ Art iculation \%20Agreement $\% 202004$.pdf

Mickelson, R. A. (2003). When are racial disparities in education the result of racial discrimination? A social science perspective. Teachers College Record, 105(6), 1052-1086. https://psycnet.apa.org/doi/10.1111/1467-9620.00277

Monaghan, D., \& Attewell, P. (2015). The community college route to the bachelor's degree. Educational Evaluation and Policy Analysis, 37(1), 70-91. https://www.jstor.org.prox.lib.ncsu.edu/stable/43773487 
National Center for Education Statistics. (n.d.). Total fall enrollment in degree-granting postsecondary institutions, by control and classification of institution, level of enrollment, and race/ethnicity of student: 2016. [Table of values]. https://nces.ed.gov/programs/digest/d17/tables/dt17 306.50.asp

The North Carolina Community College System. (2019). 2019 equity report: Identifying access and academic progress gaps in the North Carolina Community College System. https:/ / www.nccommunitycolleges.edu/analytics/equity-report

The North Carolina Community College System. (2020). College transferperformance - Institutional outcomes. [Charts and graphs of performance data]. https://www.nccommunitycolleges.edu/analytics/dashboards

O’Meara, R., Carmichael, M., \& Hall, T. (2007). A discussion of past, present, and future articulation models at postsecondary institutions. The Journal of Technology Studies, 33(1/2), 9-16. https://doi.org/10.21061/jots.v33i1.a.2

Orozco, G. L., Alvarez, A. N., \& Gutkin, T. (2010). Effective advising of diverse students in community colleges. Community College Journal of Research and Practice, 34(9), 717-737. https://doi.org/10.1080/10668920701831571

Parekh, G., \& Brown, R. S. (2018) Changing lanes: The relationship between special education placement and students' academic futures. Educational Policy, 33(1), 111-135. https://doi.org/10.1177/0895904818812772

Perna, L. W. (2006). Studying college access and choice: A proposed conceptual model. In J. C. Smart (Ed.), Higher education: Handbook of theory and research, 21 (pp. 99-157). Springer.

Rankin, S.R., \& Reason, R.D. (2005). Differing perceptions: How students of Color and white students perceive campus climate for underrepresented groups. Journal of College Student Development 46(1), 43-61. https://doi.org/10.1353/csd.2005.0008

Roksa, J. (2006). States, schools and students: Contextualizing community college outcomes [Unpublished doctoral dissertation]. New York University, New York, NY.

Roksa, J., \& Keith, B. (2008). Credits, time, and attainment: Articulation policies and success after transfer. Educational Evaluation and Policy Analysis, 30(3), 236-254. https://doi.org/10.3102/0162373708321383

Senie, K.C. (2016). Implementing transfer and articulation: A case study of community colleges and state universities. Community College Journal of Research and Practice, 40(4), 269-284. https://doi/10.1080/10668926.2015.1038667

Shapiro, D., Dundar, A., Huie, F., Wakhungu, P. K., Yuan, X., Nathan, A., \& Hwang, Y. (2017). Tracking transfer: Measures of effectiveness in helping community college students to complete bachelor's degrees. Signature Report, (13), 1-31.

Shapiro, D., Dundar, A., Huie, F., Wakhungu, P. K., Bhimdiwali, A., Nathan, A., \& Youngsik, H. (2018). Transfer and mobility: A national view of student movement in postsecondary institutions, Fall 2011 cohort [Signature Report No. 15]. National Student Clearinghouse Research Center.

Stage, F. K. (2007). Answering critical questions using quantitative data. New Directions for Institutional Research, 133, 5-16.

Stern, J. M. (2016). The effect of articulation agreements on community college transfers and bachelor's degree attainment. Community College Journal of Research and Practice, 40(5), 3555-369. https://doi.org/10.1080/10668926.2015.1065209

Sutherland, K., Davis, C., Terton, U., \& Visser, I. (2018). University student social media use and its influence on offline engagement in higher educational communities. Student Success, 9(2), 1324. https://doi/10.5204/ssj.v9i2.400

Taylor, Z. W. (2019). Inarticulate transfer: Do community college students understand articulation agreements? Community College Journal of Research and Practice, 43(1) 65-69. https://doi/10.1080/10668926.2017.1382400 
Teranishi, R. T. (2007). Race, ethnicity, and higher education policy: The use of critical quantitative research. New Directions for Institutional Research, 2007(133), 37-49. https://doi.org/10.1002/ir.203

The United States Census Bureau. (2017). The digital divide: Percentage of households by broadband internet subscription, computer type, race and Hispanic origin. https://www.census.gov/library/visualizations/2017/comm/internet.html

The United States Census Bureau. (2019a). Unemployment rates and earnings by educational attainment [Graph of data]. https://www.bls.gov/emp/chart-unemployment-earnings-education.htm

The United States Census Bureau (2019b). National Population by Characteristics: 2010-2019 [Charts of population characteristics]. https://www.bls.gov/emp/chart-unemployment-earningseducation.htm

The United States Census Bureau. (2019c). Quick facts: North Carolina [Charts of population characteristics]. https://www.census.gov/quickfacts

The University of North Carolina at Chapel Hill. (2020). Cost of attendance. https://admissions.unc.edu/afford/cost-of-attendance/

The University of North Carolina System, \& The North Carolina Community College System. (1997, January 1). A joint effort to further simplify and facilitate transfer of credit between institutions. Copy in possession of Sondra Jarvis at the North Carolina Community College System Office.

The University of North Carolina System, \& The North Carolina Community College System. (2014, February 21). 2014 comprehensive articulation agreement between the University of North Carolina and the North Carolina Community College System. https://www.nccommunitycolleges.edu/sites/default/files/basic-pages/academicprograms/attachments/caa_final_04-25-13vs2.pdf

The University of North Carolina System. (2020). Transfer students: Interactive data dashboard [Charts and graphs of transfer enrollment data]. https://www.northcarolina.edu/impact/stats-datareports/

Umbach, P. D., Tuchmayer, J. B., Clayton, A. B., \& Smith, K. N. (2019). Transfer student success: Exploring community college, university, and individual predictors. Community College Journal of Research and Practice, 43(9), 599-617. https:/ / doi.org/10.1080/10668926.2018.1520658

Walker, K. Y., \& Okpala, C. (2017). Exploring community college students' transfer experiences and perceptions and what they believe administration can do to improve their experiences. The Journal of Continuing Higher Education, 65(1), 35-44.

Western Interstate Commission for Higher Education (WICHE). (2010). Promising practices in statewide articulation and transfer systems [Publication No. 2A373]. https://www.wiche.edu/pub/14202

Xu, D., Jaggars, S.S., Fletcher, J., \& Fink, J.E. (2018). Are community college transfer students “a good bet" for 4-year admissions? comparing academic and labor-market outcomes between transfer and native 4-year college students. The Journal of Higher Education, 89(4), 478-502. https://doi/10.1080/00221546.2018.1434280

Ziedenberg, M. (2015). Valuable learning or "spinning their wheels"? Understanding excess credits earned by community college associate degree completers. Community College Review, 43(2), 123-141. https://doi.org/10.1177/0091552115571595 


\section{Rachel Worsham}

\section{About the Authors}

North Carolina State University

reworsha@,ncsu.edu

https://orcid.org/0000-0002-6325-1144

Rachel Worsham is a doctoral candidate at North Carolina State University. Drawing from her experience as a college adviser, Rachel's research centers on postsecondary access for lowincome, first-generation, and students of Color.

\section{Melissa Whatley}

North Carolina State University

mewhatle@,ncsu.edu

Melissa Whatley, Ph.D., is a postdoctoral research scholar in the Belk Center for Community College Leadership and Research. Her work focuses on issues surrounding access and equity in international education, particularly at community colleges.

\section{Jonathan Loss}

Catawba Valley Community College

jloss@,cvcc.edu

Jonathan Loss is a doctoral candidate in Community College Leadership at North Carolina State University and serves in the role of Dean for the School of Academics and Educational Opportunities at Catawba Valley Community College. Jonathan has been involved in multiple statewide initiatives and projects for the NCCCS and the University of North Carolina (UNC) System including the joint Transfer Advisory Committee (TAC). These service opportunities have led to the development of an affinity for research centered on transfer students between the two systems of higher education in North Carolina.

\section{About the Editors}

\section{Eric R. Felix}

San Diego State University

efelix@sdsu.edu

https://orcid.org/0000-0002-6116-0214

Eric R. Felix is a critical policy scholar examining the ways policymakers craft higher education reform and how institutional leaders implement them. His research focuses on understanding how policy implementation may benefit, harm, or render invisible Latinx students and other minoritized groups in the community college context.

\section{H. Kenny Nienhusser}

University of Connecticut

kenny.nienhusser@uconn.edu

https://orcid.org/0000-0001-9013-0682

H. Kenny Nienhusser is an Assistant Professor in the Higher Education \& Student Affairs Program in the Neag School of Education and Faculty Director of La Comunidad Intelectual at the University of Connecticut. His research examines the origins of public policies and their implementation environments that affect the postsecondary education access of minoritized youth in the United States. 


\section{Ángel de Jesus Gonzalez}

San Diego State University

agonzalez2426@sdsu.edu

https://orcid.org/0000-0001-6361-7399

Ángel de Jesus Gonzalez is a third-year doctoral candidate in the Community College

Leadership Ed.D. program at San Diego State University. Their research examines the conditions, experiences, and outcomes for LGBTQ+ students at community colleges, with a focus on Queer Latinx students and professionals.

\section{Luz Burgos-López}

University of Connecticut-Storrs

luz.burgos_lopez@uconn.edu

https://orcid.org/0000-0002-2394-4456

Luz Burgos-López is a second year doctoral student in the Learning, Leadership, and Educational Policy Ph.D program at the Neag School of Education, University of Connecticut. Her research explores anti-Black ideology in existing research pedagogy on the Latinx students and the role racial classifications in scholarship production and policy implantation within higher education. Her current research project uses critical analysis of the construction of Latinidad as a racial classification to examine the erasure of Blackness and the monolith representation of Latinidad.

\section{SPECIAL ISSUE \\ Policy Implementation as an Instrument to Achieve Educational Equity in the Community College Context education policy analysis archives}

Volume 29 Number 28
March 8, 2021
ISSN 1068-2341



Readers are free to copy, display, distribute, and adapt this article, as long as the work is attributed to the author(s) and Education Policy Analysis Archives, the changes are identified, and the same license applies to the derivative work. More details of this Creative Commons license are available at https://creativecommons.org/licenses/by-sa/4.0/. EPAA is published by the Mary Lou Fulton Institute and Graduate School of Education at Arizona State University Articles are indexed in CIRC (Clasificación Integrada de Revistas Científicas, Spain), DIALNET (Spain), Directory of Open Access Journals, EBSCO Education Research Complete, ERIC, Education Full Text (H.W. Wilson), QUALIS A1 (Brazil), SCImago Journal Rank, SCOPUS, SOCOLAR (China).

Please send errata notes to Audrey Amrein-Beardsley at audrey.beardsley@asu.edu

Join EPAA's Facebook community at https://www.facebook.com/EPAAAAPE and Twitter feed@epaa_aape. 


\section{education policy analysis archives editorial board}

Lead Editor: Audrey Amrein-Beardsley (Arizona State University)

Editor Consultor: Gustavo E. Fischman (Arizona State University)

Associate Editors: Melanie Bertrand, David Carlson, Lauren Harris, Danah Henriksen, Eugene Judson, Mirka

Koro-Ljungberg, Daniel Liou, Scott Marley, Keon McGuire, Molly Ott, Iveta Silova (Arizona State University)

Madelaine Adelman Arizona State

University

Cristina Alfaro

San Diego State University

Gary Anderson

New York University

Michael W. Apple

University of Wisconsin, Madison

Jeff Bale University of Toronto,

Canada

Aaron Benavot SUNY Albany

David C. Berliner

Arizona State University

Henry Braun Boston College

Casey Cobb

University of Connecticut

Arnold Danzig

San Jose State University

Linda Darling-Hammond

Stanford University

Elizabeth H. DeBray

University of Georgia

David E. DeMatthews

University of Texas at Austin

Chad d'Entremont Rennie Center

for Education Research \& Policy

John Diamond

University of Wisconsin, Madison

Matthew Di Carlo

Albert Shanker Institute

Sherman Dorn

Arizona State University

Michael J. Dumas

University of California, Berkeley

Kathy Escamilla

University of Colorado, Boulder

Yariv Feniger Ben-Gurion

University of the Negev

Melissa Lynn Freeman

Adams State College

Rachael Gabriel

University of Connecticut
Amy Garrett Dikkers University

of North Carolina, Wilmington

Gene V Glass

Arizona State University

Ronald Glass University of

California, Santa Cruz

Jacob P. K. Gross

University of Louisville

Eric M. Haas WestEd

Julian Vasquez Heilig California State University, Sacramento

Kimberly Kappler Hewitt

University of North Carolina

Greensboro

Aimee Howley Ohio University

Steve Klees University of Maryland

Jaekyung Lee SUNY Buffalo

Jessica Nina Lester

Indiana University

Amanda E. Lewis University of

Illinois, Chicago

Chad R. Lochmiller Indiana

University

Christopher Lubienski Indiana

University

Sarah Lubienski Indiana University

William J. Mathis

University of Colorado, Boulder

Michele S. Moses

University of Colorado, Boulder

Julianne Moss

Deakin University, Australia

Sharon Nichols

University of Texas, San Antonio

Eric Parsons

University of Missouri-Columbia

Amanda U. Potterton

University of Kentucky

Susan L. Robertson

Bristol University
Gloria M. Rodriguez

University of California, Davis

R. Anthony Rolle

University of Houston

A. G. Rud

Washington State University

Patricia Sánchez University of

University of Texas, San Antonio

Janelle Scott University of

California, Berkeley

Jack Schneider University of

Massachusetts Lowell

Noah Sobe Loyola University

Nelly P. Stromquist

University of Maryland

Benjamin Superfine

University of Illinois, Chicago

Adai Tefera

Virginia Commonwealth University

A. Chris Torres

Michigan State University

Tina Trujillo

University of California, Berkeley

Federico R. Waitoller

University of Illinois, Chicago

Larisa Warhol

University of Connecticut

John Weathers University of

Colorado, Colorado Springs

Kevin Welner

University of Colorado, Boulder

Terrence G. Wiley

Center for Applied Linguistics

John Willinsky

Stanford University

Jennifer R. Wolgemuth

University of South Florida

Kyo Yamashiro

Claremont Graduate University

Miri Yemini

Tel Aviv University, Israel 


\section{archivos analíticos de políticas educativas consejo editorial}

Editor Consultor: Gustavo E. Fischman (Arizona State University)

Coordinador (Español/Latinoamérica): Ignacio Barrenechea (Universidad de San Andrés), Ezequiel Gomez Caride (Universidad de San Andres/ Pontificia Universidad Católica Argentina)

Editor Coordinador (Español/Norteamérica): Armando Alcántara Santuario (Universidad Nacional Autónoma de México) Editor Coordinador (Español/España): Antonio Luzon (Universidad de Granada)

Editores Asociados: Jason Beech (Monash University), Angelica Buendia, (Metropolitan Autonomous University), Gabriela de la Cruz Flores (Universidad Nacional Autónoma de Mëxico), Alejandra Falabella (Universidad Alberto Hurtado, Chile), Carmuca Gómez-Bueno (Universidad de Granada), Carolina Guzmán-Valenzuela (Universidade de Chile), Cesar Lorenzo Rodriguez Uribe (Universidad Marista de Guadalajara), Antonia Lozano-Díaz (University of Almería), Sergio Gerardo Málaga Villegas (Instituto de Investigación y Desarrollo Educativo, Universidad Autónoma de Baja California (IIDE-UABC)), María Teresa Martín Palomo (University of Almería), María Fernández MellizoSoto (Universidad Complutense de Madrid), Tiburcio Moreno (Autonomous Metropolitan University-Cuajimalpa Unit), José Luis Ramírez, (Universidad de Sonora), Axel Rivas (Universidad de San Andrés), Maria Veronica Santelices (Pontificia Universidad Católica de Chile)

Claudio Almonacid

Universidad Metropolitana de

Ciencias de la Educación, Chile

Miguel Ángel Arias Ortega

Universidad Autónoma de la

Ciudad de México

Xavier Besalú Costa

Universitat de Girona, España

Xavier Bonal Sarro Universidad

Autónoma de Barcelona, España

Antonio Bolívar Boitia

Universidad de Granada, España

José Joaquín Brunner Universidad Diego Portales, Chile

Damián Canales Sánchez Instituto Nacional para la Evaluación de la Educación, México

Gabriela de la Cruz Flores

Universidad Nacional Autónoma de México

Marco Antonio Delgado Fuentes

Universidad Iberoamericana, México

Inés Dussel, DIE-CINVESTAV, México

Pedro Flores Crespo Universidad Iberoamericana, México

\section{Ana María García de Fanelli \\ Centro de Estudios de Estado y \\ Sociedad (CEDES) CONICET, Argentina \\ Juan Carlos González Faraco \\ Universidad de Huelva, España \\ María Clemente Linuesa \\ Universidad de Salamanca, España \\ Jaume Martínez Bonafé \\ Universitat de València, España}

Alejandro Márquez Jiménez

Instituto de Investigaciones sobre la

Universidad y la Educación,

UNAM, México

María Guadalupe Olivier Tellez, Universidad Pedagógica Nacional, México

Miguel Pereyra Universidad de Granada, España

Mónica Pini Universidad Nacional de San Martín, Argentina

Omar Orlando Pulido Chaves Instituto para la Investigación Educativa y el Desarrollo Pedagógico (IDEP)

José Ignacio Rivas Flores Universidad de Málaga, España
Miriam Rodríguez Vargas

Universidad Autónoma de

Tamaulipas, México

José Gregorio Rodríguez Universidad Nacional de Colombia, Colombia

Mario Rueda Beltrán Instituto de Investigaciones sobre la Universidad y la Educación, UNAM, México

José Luis San Fabián Maroto

Universidad de Oviedo, España

Jurjo Torres Santomé, Universidad de la Coruña, España

Yengny Marisol Silva Laya

Universidad Iberoamericana, México

Ernesto Treviño Ronzón Universidad Veracruzana, México

Ernesto Treviño Villarreal Universidad Diego Portales Santiago, Chile

Antoni Verger Planells Universidad Autónoma de Barcelona, España

Catalina Wainerman Universidad de San Andrés, Argentina Juan Carlos Yáñez Velazco Universidad de Colima, México 


\section{arquivos analíticos de políticas educativas conselho editorial}

Editor Consultor: Gustavo E. Fischman (Arizona State University)

Editoras Coordenadores: Marcia Pletsch, Sandra Regina Sales (Universidade Federal Rural do Rio de Janeiro)

Editores Associadas: Andréa Barbosa Gouveia (Universidade Federal do Paraná), Kaizo Iwakami Beltrao, (EBAPE/FGVI), Sheizi Calheira de Freitas (Federal University of Bahia), Maria Margarida Machado (Federal University of Goiás / Universidade Federal de Goiás), Gilberto José Miranda (Universidade Federal de Uberlândia)

\section{Almerindo Afonso \\ Universidade do Minho \\ Portugal}

\section{Rosanna Maria Barros Sá \\ Universidade do Algarve \\ Portugal}

\section{Maria Helena Bonilla \\ Universidade Federal da Bahia \\ Brasil}

Rosa Maria Bueno Fischer

Universidade Federal do Rio Grande do Sul, Brasil

\section{Alice Casimiro Lopes \\ Universidade do Estado do Rio de \\ Janeiro, Brasil}

\section{Suzana Feldens Schwertner \\ Centro Universitário Univates \\ Brasil}

\section{Geovana Mendonça Lunardi \\ Mendes Universidade do Estado de Santa Catarina}

\section{Flávia Miller Naethe Motta \\ Universidade Federal Rural do Rio de Janeiro, Brasil}

\section{Alexandre Fernandez Vaz \\ Universidade Federal de Santa \\ Catarina, Brasil}

\section{Regina Célia Linhares Hostins \\ Universidade do Vale do Itajaí, Brasil}

Alfredo Macedo Gomes
Universidade Federal de Pernambuco
Brasil

Jefferson Mainardes

Universidade Estadual de Ponta

Grossa, Brasil

Jader Janer Moreira Lopes

Universidade Federal Fluminense e

Universidade Federal de Juiz de Fora, Brasil

Debora Nunes

Universidade Federal do Rio Grande do Norte, Brasil

\section{Alda Junqueira Marin \\ Pontifícia Universidade Católica de São Paulo, Brasil}

\section{Dalila Andrade Oliveira}

Universidade Federal de Minas

Gerais, Brasil
José Augusto Pacheco

Universidade do Minho, Portugal

Jane Paiva

Universidade do Estado do Rio de

Janeiro, Brasil

\section{Paulo Alberto Santos Vieira}

Universidade do Estado de Mato

Grosso, Brasil

Fabiany de Cássia Tavares Silva

Universidade Federal do Mato

Grosso do Sul, Brasil

António Teodoro

Universidade Lusófona

Portugal

\section{Lílian do Valle}

Universidade do Estado do Rio de Janeiro, Brasil

\section{Alfredo Veiga-Neto}

Universidade Federal do Rio Grande do Sul, Brasil 